\title{
An assessment of the genus Columbella Lamarck, 1799 (Gastropoda: Columbellidae) from eastern Atlantic
}

\author{
Valeria RUSSINI \\ Giulia FASSIO \\ Maria Vittoria MODICA \\ Department of Biology and Biotechnologies "Charles Darwin", \\ Sapienza University of Rome, Viale dell'Università 32, I-00185 Roma (Italy) \\ Marta J. deMAINTENON \\ University of Hawaii at Hilo, 200 W. Kawili Street, Hilo, HI 96720 (United States) \\ Marco OLIVERIO \\ Department of Biology and Biotechnologies "Charles Darwin", \\ Sapienza University of Rome, Viale dell'Università 32, I-00185 Roma (Italy) \\ marco.oliverio@uniroma1.it \\ (corresponding author)
}

Published on 30 June 2017

urn:Isid:zoobank.org:pub:57395522-BE12-40AC-B504-C448A31F8A8D

Russini V., Fassio G., Modica M. V., deMaintenon M. J. \& Oliverio M. 2017. - An assessment of the genus Columbella Lamarck, 1799 (Gastropoda: Columbellidae) from eastern Atlantic. Zoosystema 39 (2): 197-212. https://doi. org/10.5252/z2017n2a2

KEY WORDS

Columbellidae,

East Atlantic,

Mediterranean,

lectotypification,

DNA-Barcoding.

MOTS CLÉS

Columbellidae,

Atlantique de l'est,

Mediterranée,

lectotypification

DNA-Barcoding.

\begin{abstract}
Three species of the neogastropod genus Columbella Lamarck, 1799 are recognised from the northeastern Atlantic and the Mediterranean. One is the common Mediterranean C. rustica (Linnaeus, 1758), with paucispiral protoconch, extending its range in the Atlantic South to Senegal and North to Portugal. Columbella adansoni Menke, 1853, with multispiral protoconch is restricted to the Macaronesian archipelagoes. A third species, also with multispiral protoconch, from West Africa is recognised through molecular methods, and the name C. xiphitella Duclos, 1840 is employed by correcting the original erroneous locality ("Californie") to Gabon. Except for protoconch features, no major morphological characters are available to separate the three species; however diagnostic species-level differences in specific positions in the cytochrome c oxidase I (COI) sequences are present between all three species.

\section{RÉSUMÉ}

Étude du genre Columbella Lamarck, 1799 (Gastropoda: Columbellidae) dans l'Est de l'océan Atlantique. Trois espèces du genre de néogastropode Columbella Lamarck, 1799 sont reconnues dans le nord est de l'Atlantique et en Méditerranée. L'une est courante en Méditerranée, C. rustica (Linnaeus, 1758), au protoconche paucispiralé: son aire de répartition s'étend en Atlantique du Sénégal au nord du Portugal. Columbella adansoni Menke, 1853, au protoconche multispiralé, se limite aux archipels Macaronésiens. Une troisième espèce, caractérisée également par un protoconche multispiralé, est originaire d'Afrique de l'Ouest : elle est reconnue par des méthodes moléculaires; le nom de C. xiphitella Duclos, 1840 lui est attribué après correction de la localité originale erronée ("Californie») en Gabon. Mis à part l'aspect du protoconche, aucun caractère morphologique majeur ne permet de séparer les trois espèces; cependant des positions précises dans les séquences du cytochrome c oxidase I (COI) présentent des différences supportant des diagnoses spécifiques.
\end{abstract}




\section{INTRODUCTION}

Columbella Lamarck, 1799 s.s. (type species Voluta mercatoria Linnaeus, 1758) is a genus of columbellid neogastropods (dove shells) including 17 recognised species, mostly from tropical America and the East Atlantic/Mediterranean (WoRMS: Bouchet \& Gofas 2015). Based on Moolenbeek \& Hoenselaar (1991), Oliverio (1995), Rolán (2005), and Rolán \& Ryall (1999), two species are currently recorded in the eastern Atlantic and the Mediterranean Sea: Columbella rustica (Linnaeus, 1758), ranging over the entire Mediterranean Sea, and extending into the neighbouring Atlantic southward to Senegal, and northward to Portugal (it is absent in Galicia); and Columbella adansoni Menke, 1853, described from Cape Verde islands, and assumed to occur across Macaronesia, from the Azores to the Canary Islands, and along the West African coasts from Ghana to Angola (Oliverio 1995; Rolán \& Ryall 1999; Rolán 2005). Columbella rustica has a paucispiral protoconch, indicating nonplanktotrophic development (lecithotrophic, possibly entirely or mostly intracapsular), whereas Columbella adansoni has a multispiral protoconch, indicating planktotrophic larval development. This is the only consistent morphological diagnostic feature for the two species, which are otherwise quite variable in shell sculpture, colour and pattern. Preliminary to a study of the bearing of different larval developmental strategies on the genetic structure of populations (Modica et al. 2017), we decided to assay samples of Columbella from the eastern Atlantic and the Mediterranean to test the currently accepted species boundaries by molecular data. Therefore, we examined specimens collected from localities spanning as much as possible the known range for the genus in the eastern Atlantic. As a result, a third species of Columbella was discovered.

\section{MATERIAL AND METHODS}

Sampling locality data (Fig. 1), Identification (ID) catalogue numbers of the vouchers, and GenBank accession numbers are reported in Table 1. A total of 29 specimens from the East Atlantic and the Mediterranean were assayed. Specimens were sampled by SCUBA or snorkelling, and fixed in 95 to $100 \%$ ethanol. Vouchers are stored in the malacological collection at Department of Biology and Biotechnologies "Charles Darwin" ("La Sapienza” University of Rome) under BAU ID numbers and at Muséum national d'Histoire naturelle (Paris) under MNHN ID numbers. Genomic DNA was extracted using a proteinase K-phenol-chloroform protocol (Oliverio \& Mariottini 2001). The DNA-barcode fragment of the mitochondrial cytochrome c oxidase I (COI) and part of the $16 \mathrm{~S}$ rRNA were amplified by PCR using the universal primers LCO1490 and HCO2198 (Folmer et al. 1994) and 16SA (Palumbi et al. 2002) and CGLeuUUR (Hayashi 2003), respectively. For some crucial specimens from West Africa, fixed in alcohol but thereafter preserved dried, which were unsuccessfully assayed with the pair
HCO2198-LCO1490, we employed HCO2198 with the primer mlCOIint-F (5'-GGWACWGGWTGAACWGTWTAYCCYCC-3') designed to amplify a shorter fragment (c. $300 \mathrm{bp}$ ) and employed in metabarcoding works (Leray et al. 2013). PCR amplifications were performed with the following conditions: initial denaturation of $5^{\prime}$ at $94^{\circ} \mathrm{C}$, 35 amplification cycles $\left(30^{\prime \prime} / 94^{\circ} \mathrm{C}, 40 " / 48-52^{\circ} \mathrm{C}, 50^{\prime \prime} / 72^{\circ} \mathrm{C}\right)$, followed by a final phase of $7^{\prime}$ at $72^{\circ} \mathrm{C}$. PCR products were purified by ExoSAP-IT protocol (USB Corporation, Ohio, USA) and Sanger sequenced by Macrogen Inc. (The Netherlands). Forward and reverse sequences were assembled, checked for contamination and edited with Geneious 4.8.5 (Drummond et al. 2009).

Species delimitation in Columbellidae Swainson, 1840 A total of 106 COI sequences from columbellid specimens ascribed to the genera Alia H. Adams \& A. Adams, 1853, Amphissa H. Adams \& A. Adams, 1853, Euplica Dall, 1889, Graphicomassa Iredale, 1929, Indomitrella Oostingh, 1940, Mitrella Risso, 1826, Pyrene Röding, 1798, Sulcomitrella Kuroda, Habe \& Oyama, 1971 and Zafra A. Adams, 1860 (plus some labelled as "columbellid indet.") were either provided by Nicolas Puillandre (ID MNHN-IM) or were retrieved from the GenBank (see Table 4). Sequences from Cancellopollia sp. (Gastropoda, Buccinoidea, Buccinidae) (EU015666.1; voucher MNHN-IM-2009-17854), and Pisania striata Duclos, 1840 (MNHN-IM-2009-30664, Gastropoda, Buccinoidea, Buccinidae) were retrieved from Genbank to be used as outgroups. COI sequences were manually aligned and checked for stop codons; $16 \mathrm{~S}$ sequences were aligned using MAFFT 7 (Katoh et al. 2002), using the Q-INS-i algorithm (Katoh \& Toh 2008), which accounts for secondary structures. Highly variable regions, resulting in gap-rich fragments with ambiguous alignment, were discarded using Gblocks 0.91b (Castresana 2000). All alignments are available from the authors on request.

To define species, we used Automatic Barcode Gap Discovery (ABGD, available at http://wwwabi.snv.jussieu.fr/ public/abgd/), a distance-based method designed to detect the so-called "barcode gap" in the distribution of pairwise distances estimated in a COI alignment (Puillandre et al. 2012a, b), and the criteria of divergence and reciprocal monophyly (Knowlton 2000; Wheeler \& Meier 2000; Reid et al. 2006; Malaquias \& Reid 2009). The COI sequence alignments were processed in ABGD (excluding the outgroups) using the Kimura-2-parameter (K2p) model and the following settings: a prior for the maximum value of intraspecific divergence between 0.001 and $0.1,25$ recursive steps within the primary partitions defined by the first estimated gap, and a gap width of 0.1 .

We ran ABGD on the whole columbellid dataset of $136 \mathrm{COI}$ sequences, to define partition scheme(s) based on distance distribution. Then, species hypotheses as derived from ABGD were tested against taxonomic recognition for the assayed specimens and for phylogenetic congruence. Phylogenetic analyses of the COI, $16 \mathrm{~S}$ and combined sequence alignments were conducted using Maximum likelihood (ML: 


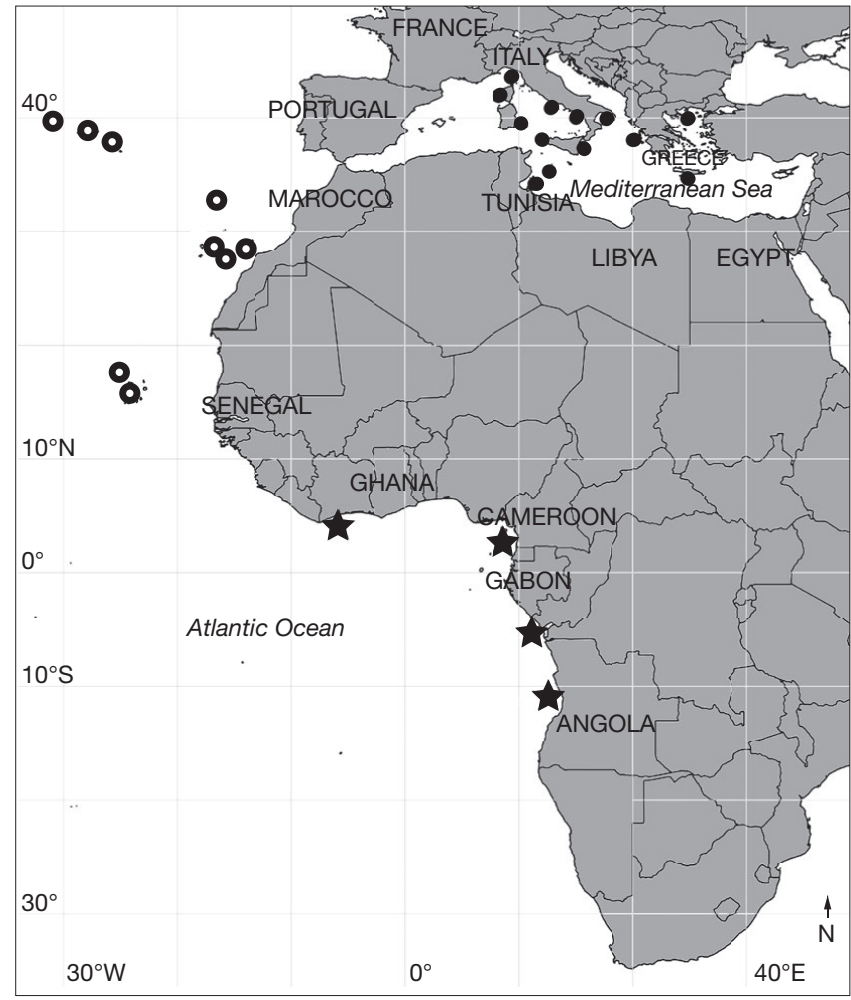

FIG. 1. - Map of the collecting sites (for details see Table 1). Symbols: -, Columbella rustica (Linnaeus, 1758); O, Columbella adansoni Menke, 1853; $\star$, Columbella xiphitella Duclos, 1840.

with 1000 bootstrap replicates) by PhyML3.0 (http://www. atgc-montpellier.fr/phyml/) and Bayesian inference (BI: four-chain Markov chain Monte Carlo (MCMC) analysis, run twice in parallel for $10^{7}$ generations; trees sampled every 1000 generations, burn-in 2500) by MrBayes 3.2.3 on the XSEDE resources on CIPRES Science Gateway V.3.3 portal (https://www.phylo.org/), both with the HKY + I + G (Hasegawa et al. 1985) nucleotide substitution model, as selected by jModelTest2. Same analyses (ABGD, ML and $\mathrm{BI})$ were performed on a reduced dataset including sequences from the eastern Atlantic specimens (including full length and shorter COI sequences), sequences from Columbella mercatoria (Linnaeus, 1758) (type species of the genus Columbella) and Columbella major Sowerby, 1832, while those from Euplica turturina (Lamarck, 1822) (JQ950207.1 and JQ950143.1, voucher MNHN-IM-2007-33524) were used as outgroup.

\section{ABBREVIATIONS}

ABGD Automatic Barcode Gap Discovery;

ICZN International Commission on Zoological Nomen$\begin{array}{ll}\text { sh } & \text { clature; } \\ \text { shell(s). }\end{array}$

\section{Institutions}

MNHN Muséum national d'Histoire naturelle, Paris;

SMF Senckenberg Forschungsinstitut und Naturmuseum, Frankfurt.

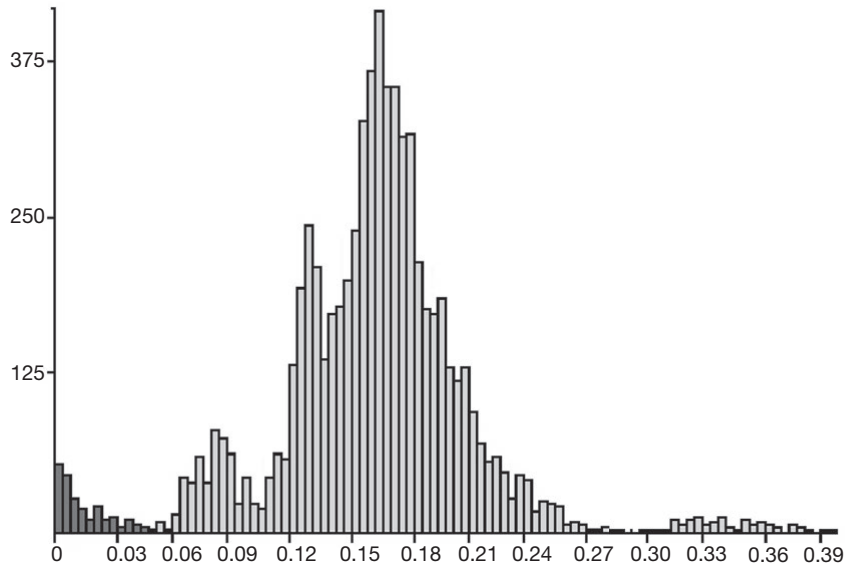

FIG. 2. - Histogram of the distribution of the pairwise estimated genetic distances (K2p) in intraspecific (left, dark grey) and interspecific (right, light grey) comparisons among Columbellidae Swainson, 1840

\section{RESULTS}

For the eastern Atlantic/Mediterranean Columbella specimens, a total of 14 specimens from the Mediterranean, nine specimens from the Macaronesia, six specimens from Gabon, three from Ghana and one each from Angola and São Tomé, yielded full length 16S (723bp). Full length COI (658bp) were obtained from 14 specimens from the Mediterranean, nine specimens from Macaronesia, six specimens from Gabon; shorter COI sequences (288bp) were obtained from two specimens from Ghana and one specimen from Angola.

\section{SPECIES DELIMITATION IN WORLDWIDE COLUMBELLIDAE} The 30 recursive steps in the $\mathrm{ABGD}$ analysis of the COI alignment converged toward a 46-species partition scheme, with the corresponding 46 species hypotheses largely congruent with the a priori morphological identification of the worldwide columbellid specimens included (Table 4). Accordingly, the intraspecific genetic divergence estimated on the COI dataset ranged from 0 to $5 \%$, the interspecific ones from 5 to $30 \%$ (Fig. 2: K2p matrices available from the authors). ML and BI phylogenetic analyses of the same dataset recovered all 25 species with multiple specimens as monophyletic with very high bootstrap (>95\%) and BI (>0.99) support.

SPECIES DELIMITATION IN EASTERN ATLANTIC COLUMBELLA The 658bp COI sequences of the eastern Atlantic/Mediterranean Columbella were split into three groups: 1) the Mediterranean specimens (corresponding to Columbella rustica); 2) the Macaronesian specimens (corresponding to C. adansoni); and 3) the specimens from Gabon. The pattern was exactly the same when the shorter sequences of specimens from Ghana and Angola were included.

Intraspecific distance ranged $0-1.5 \%$ in $C$. adansoni, $0.2-$ $3 \%$ in $C$. rustica, and $0.5-1.6 \%$ in the West African species (see Table 2 for K2p indices). The estimated genetic distance was $4 \%$ between C. rustica and C. adansoni, and $7 \%$ between the new West African species and the other two (Table 2). 
TABLE 1. - List of the examined material with ID numbers for voucher lots (BAU, Department of Biology and Biodiversity, Sapienza University of Rome; MNHN, Museum national d'Histoire naturelle, Paris), data on collecting sites (in parentheses the number used in Figure 1), and GenBank accession numbers for the sequences.

\begin{tabular}{|c|c|c|c|c|}
\hline \multirow[t]{2}{*}{ ID } & \multirow[t]{2}{*}{ Site } & \multirow[t]{2}{*}{ Coordinates } & \multicolumn{2}{|c|}{ Accession numbers } \\
\hline & & & COI & $16 S$ \\
\hline \multicolumn{5}{|c|}{ Columbella rustica (Linnaeus, 1758) } \\
\hline BAU 1608 & (1) Galeria, Corsica, France: 1-5 m depth & $42^{\circ} 25^{\prime} 16^{\prime \prime} \mathrm{N}, 8^{\circ} 37^{\prime} 26^{\prime \prime} \mathrm{E}$ & KX639980 & \\
\hline BAU 1670 & (2) S. Isidoro, Italy: 1-5 m depth & $40^{\circ} 12^{\prime} 15^{\prime \prime} \mathrm{N}, 17^{\circ} 55^{\prime} 12^{\prime \prime} \mathrm{E}$ & KX639897 & \\
\hline BAU 1755 & (3) Palinuro, Italy: 1-7 m depth & $40^{\circ} 01^{\prime} 53^{\prime \prime} \mathrm{N}, 15^{\circ} 16^{\prime} 07^{\prime \prime} \mathrm{E}$ & KX639898 & \\
\hline BAU 1779 & (4) Cape Tenafo, Greece: $1 \mathrm{~m}$ depth & $36^{\circ} 23^{\prime} 07^{\prime \prime} \mathrm{N}, 22^{\circ} 28^{\prime} 58^{\prime \prime} \mathrm{E}$ & KX639914 & $\begin{array}{l}\text { KX664064 } \\
\text { KX664065 } \\
\text { KX664066 }\end{array}$ \\
\hline BAU 1794 & (5) Sidi Jmour, Djerba, Tunisia: 0-1 m depth & $33^{\circ} 49^{\prime} 53^{\prime \prime} \mathrm{N}, 10^{\circ} 44^{\prime} 50^{\prime \prime} \mathrm{E}$ & KX639919 & \\
\hline BAU 807 & (6) Ognina Cuba, Sicily, Italy: 0-1 m depth & $36^{\circ} 58^{\prime} 20^{\prime \prime} \mathrm{N}, 15^{\circ} 14^{\prime} 55^{\prime \prime} \mathrm{E}$ & $\begin{array}{l}\text { KX639923 } \\
\text { KX639925 }\end{array}$ & \\
\hline BAU 811 & (7) Giraglia, Corsica, France: 0-1 m depth & $43^{\circ} 00^{\prime} 37^{\prime \prime} \mathrm{N}, 009^{\circ} 25^{\prime} 27^{\prime \prime} \mathrm{E}$ & KX639976 & $\begin{array}{l}\text { KX664073 } \\
\text { KX664074 } \\
\text { KX664075 }\end{array}$ \\
\hline BAU 816 & (8) Isola dei conigli, Lampedusa, Italy: 0-2 m depth & $35^{\circ} 30^{\prime} 35^{\prime \prime} \mathrm{N}, 12^{\circ} 33^{\prime} 27^{\prime \prime} \mathrm{E}$ & KX639933 & \\
\hline BAU 818 & (9) Marsala, Sicily, Italy: 0-1 m depth & $37^{\circ} 47^{\prime} 32^{\prime \prime} \mathrm{N}, 12^{\circ} 25^{\prime} 50^{\prime \prime} \mathrm{E}$ & KX639940 & $\begin{array}{l}\text { KX664076 } \\
\text { KX664077 } \\
\text { KX664078 }\end{array}$ \\
\hline BAU 819 & (10) Agios Georgos, Corfù, Greece: 1-3 m depth & $39^{\circ} 43^{\prime} 07^{\prime \prime} \mathrm{N}, 19^{\circ} 39^{\prime} 44^{\prime \prime} \mathrm{E}$ & KX639946 & \\
\hline BAU 822 & (11) Agia Pelagia, Crete, Greece: 0-3 m depth & $35^{\circ} 24^{\prime} 25.6^{\prime \prime} \mathrm{N}, 25^{\circ} 01^{\prime} 05.5^{\prime \prime} \mathrm{E}$ & KX639959 & \\
\hline BAU 829 & (12) Zannone Island, Italy: 0-10 m depth & $40^{\circ} 58^{\prime} 10^{\prime \prime} \mathrm{N}, 13^{\circ} 02^{\prime} 44^{\prime \prime} \mathrm{E}$ & KX639983 & \\
\hline BAU 831 & (13) Arbatax, Sardinia, Italy: 0-12 m depth & $39^{\circ} 55^{\prime} 19.0^{\prime \prime} \mathrm{N}, 9^{\circ} 42^{\prime} 54.9^{\prime \prime} \mathrm{E}$ & KX639987 & \\
\hline \multicolumn{5}{|c|}{ Columbella adansoni Menke, 1853} \\
\hline BAU 1123 & (14) Mindelo, São Vicente, Cape Verde: intertidal & $16^{\circ} 54^{\prime} 08^{\prime \prime} \mathrm{N}, 24^{\circ} 59^{\prime} 51^{\prime \prime} \mathrm{W}$ & KX639833 & KX664059 \\
\hline BAU 1124 & $\begin{array}{l}\text { (15) Arguineguin, Gran Canaria, Canary Islands: } \\
0-1 \text { m depth }\end{array}$ & $27^{\circ} 45^{\prime} 18^{\prime \prime} \mathrm{N}, 15^{\circ} 41^{\prime} 04^{\prime \prime} \mathrm{W}$ & KX639835 & \\
\hline BAU 1694 & (16) Sal Rei, Boavista, Cape Verde: intertidal & $16^{\circ} 11^{\prime} 5.18^{\prime \prime} \mathrm{N}, 22^{\circ} 55^{\prime} 26.70^{\prime \prime} \mathrm{W}$ & KX639841 & $\begin{array}{l}\text { KX664061 } \\
\text { KX664062 } \\
\text { KX664063 }\end{array}$ \\
\hline BAU 708 & (17) Caloura, São Miguel, Azores: 0-3 m depth & $37^{\circ} 42^{\prime} 26.8^{\prime \prime} \mathrm{N}, 25^{\circ} 30^{\prime} 16.4^{\prime \prime} \mathrm{W}$ & KX639851 & \\
\hline BAU 716 & (18) Lajes, Pico, Azores: 0-2 m depth & $38^{\circ} 23^{\prime} 05.7^{\prime \prime} \mathrm{N}, 28^{\circ} 15^{\prime} 04.2^{\prime \prime} \mathrm{W}$ & KX639859 & $\begin{array}{l}\text { KX664067 } \\
\text { KX664068 } \\
\text { KX664069 }\end{array}$ \\
\hline BAU 718 & (19) Santa Cruz, Flores, Azores: 0-2 m depth & $39^{\circ} 27^{\prime} 07.3^{\prime \prime} \mathrm{N}, 31^{\circ} 07^{\prime} 26.6^{\prime \prime} \mathrm{W}$ & KX639867 & \\
\hline BAU 802 & $\begin{array}{l}\text { (20) Puertito de Guimar, Tenerife, Canary Islands: } \\
1-2 \text { m depth }\end{array}$ & $28^{\circ} 17^{\prime} 11^{\prime \prime} \mathrm{N}, 16^{\circ} 22^{\prime} 48^{\prime \prime} \mathrm{W}$ & KX639885 & \\
\hline BAU 804 & (21) Funchal, Madeira: 1-2 m depth & $32^{\circ} 38^{\prime} 22^{\prime \prime} \mathrm{N}, 16^{\circ} 55^{\prime} 24^{\prime \prime} \mathrm{W}$ & KX639888 & \\
\hline BAU 805 & $\begin{array}{l}\text { (22) Ajuy, Fuerteventura, Canary Islands: 0-1 m } \\
\text { depth }\end{array}$ & $28^{\circ} 24^{\prime} 14^{\prime \prime} \mathrm{N}, 14^{\circ} 09^{\prime} 20^{\prime \prime} \mathrm{W}$ & KX639890 & $\begin{array}{l}\text { KX664070 } \\
\text { KX664071 } \\
\text { KX664072 }\end{array}$ \\
\hline \multicolumn{5}{|c|}{ Columbella xiphitella Duclos, 1840} \\
\hline BAU 1120 & (23) Cape Santa Clara, Libreville, Gabon: intertidal & $0^{\circ} 30^{\prime} 18^{\prime \prime} \mathrm{N}, 9^{\circ} 19^{\prime} 07^{\prime \prime} \mathrm{E}$ & KX639827 & KX664053 \\
\hline MNHN-IM-2000- & to $1 \mathrm{~m}$ depth & & KX639828 & KX664054 \\
\hline $32497 / 32498$ & & & KX639829 & KX664055 \\
\hline & & & KX639830 & KX664056 \\
\hline & & & KX639831 & KX664057 \\
\hline & & & KX639832 & KX664058 \\
\hline BAU 1118 & $\begin{array}{l}\text { (24) Praia da Corimba, Luanda, Angola: dredged in } \\
\text { c. } 20 \mathrm{~m} \text { depth }\end{array}$ & $8^{\circ} 51^{\prime} \mathrm{S}, 13^{\circ} 10^{\prime} \mathrm{E}$ & KY464898 & KX664049 \\
\hline BAU 1119 & (25) Miemia, Ghana: 1-10 m depth & $4^{\circ} 47^{\prime} 39^{\prime \prime} \mathrm{N}, 2^{\circ} 10^{\prime} 15^{\prime \prime} \mathrm{W}$ & KY464900 & KX664050 \\
\hline & & & KY464899 & $\begin{array}{l}\text { KX664051 } \\
\text { KX664052 }\end{array}$ \\
\hline BAU 1693 & (26) Lagoa Azul, São Tomé: 1-10 m depth & 024'22”'N, 6³6'29"E & & KX664060 \\
\hline \multicolumn{5}{|c|}{ Columbella major Sowerby, 1832} \\
\hline 184659143 & Venado Is., Panama. & & KY464894 & KY464896 \\
\hline \multicolumn{5}{|c|}{ Columbella mercatoria (Linnaeus, 1758) } \\
\hline 184659120 & Guadeloupe & & KY464895 & KY464897 \\
\hline
\end{tabular}




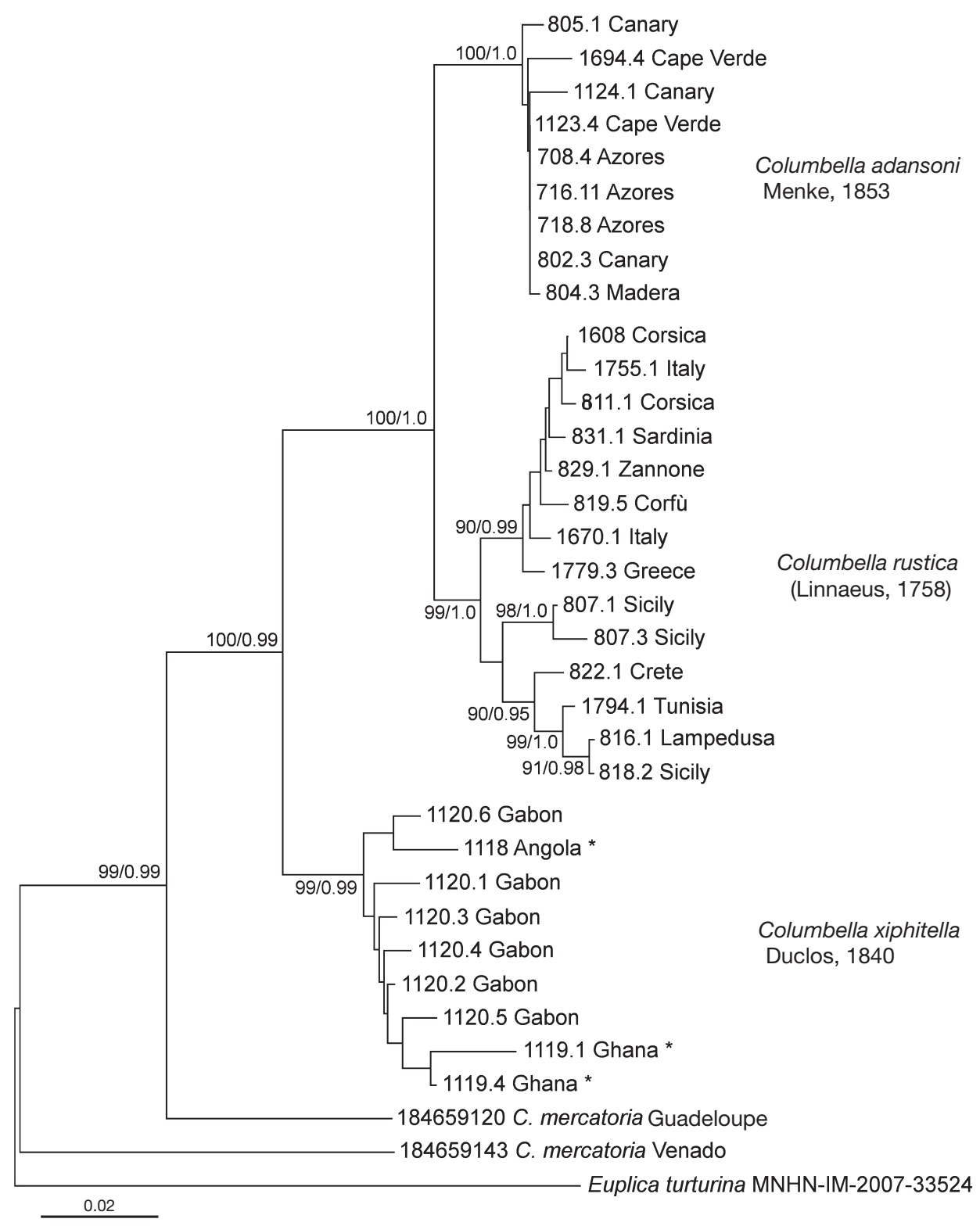

FIG. 3. - ML tree based on the COI dataset (HKY + I + G model of evolution). Numbers at nodes indicate the support by BI Bps (107 generations and $25 \%$ burnin) and ML bs (1000 replicates). Asterisks indicate shorter sequences (288 bp).

TABLE 2. - K2p genetic distance between East Atlantic and Mediterranean species of Columbella (standard deviation in parentheses).

\begin{tabular}{lcccc}
\hline \multicolumn{4}{c}{ intraspecific } & interspecific \\
\hline & $\min \max$ & mean & \\
\hline C. adansoni & 0.0000 .015 & 0.005 & \\
$\quad$ Menke, 1853 & \multicolumn{3}{c}{$(0.00)$} \\
C. rustica & 0.0020 .030 & 0.020 & 0.04 & \\
$\quad$ (Linnaeus, 1758) & & $(0.01)$ & $(0.00)$ & \\
C. xiphitella Duclos, & 0.0050 .016 & 0.011 & 0.07 & 0.07 \\
1840 & & $(0.00)$ & $(0.01)$ & $(0.01)$ \\
& & & C. adansoni C. rustica \\
\hline
\end{tabular}

TABLE 3. - Autapomorphic (diagnostic) position in the COI sequences of the three species.

\begin{tabular}{|c|c|}
\hline species & Diagnostic positions \\
\hline $\begin{array}{l}\text { C. adansoni } \\
\text { Menke, } 1853\end{array}$ & $\begin{array}{l}61[\mathrm{G}], 91[\mathrm{G}], 160[\mathrm{C}], 181[\mathrm{~T}], 352[\mathrm{C}], 549[\mathrm{~A}] \\
586[\mathrm{~T}] .\end{array}$ \\
\hline $\begin{array}{l}\text { C. rustica } \\
\text { (Linnaeus, 1758) }\end{array}$ & $238[\mathrm{C}], 310[\mathrm{~T}], 447[\mathrm{G}]$ \\
\hline $\begin{array}{l}\text { C. xiphitella } \\
\text { Duclos, } 1840\end{array}$ & $\begin{array}{l}34[\mathrm{~T}], 55[\mathrm{~T}], 78[\mathrm{G}], 100[\mathrm{~T}], 115[\mathrm{~T}], 117[\mathrm{~A}], \\
130[\mathrm{~A}], 133[\mathrm{C} / \mathrm{G}], 178[\mathrm{C}], 309[\mathrm{C}], 346[\mathrm{C}], \\
385[\mathrm{~T}], 430[\mathrm{C}], 463[\mathrm{~T}], 472[\mathrm{G}], 565[\mathrm{~T}], \\
598[\mathrm{~T}], 619[\mathrm{~T}] .\end{array}$ \\
\hline
\end{tabular}




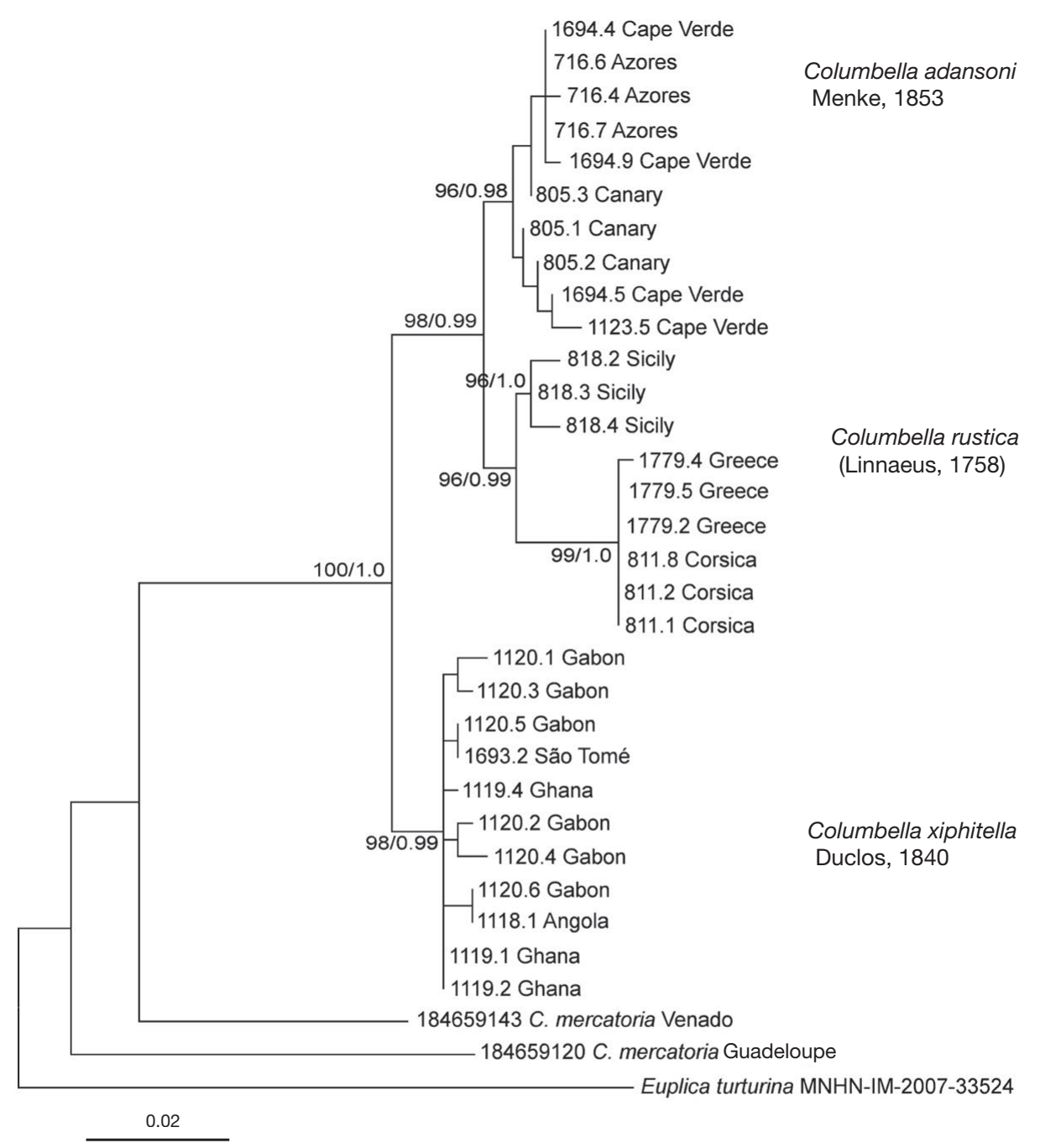

FIG. 4. - ML tree based on the $16 \mathrm{~S}$ dataset (HKY $+\mathrm{I}+\mathrm{G}$ model of evolution). Numbers at nodes indicate the support by $\mathrm{BI} \mathrm{Bps}\left(10^{7}\right.$ generations and $25 \%$ burn in) and ML bs (1000 replicates).

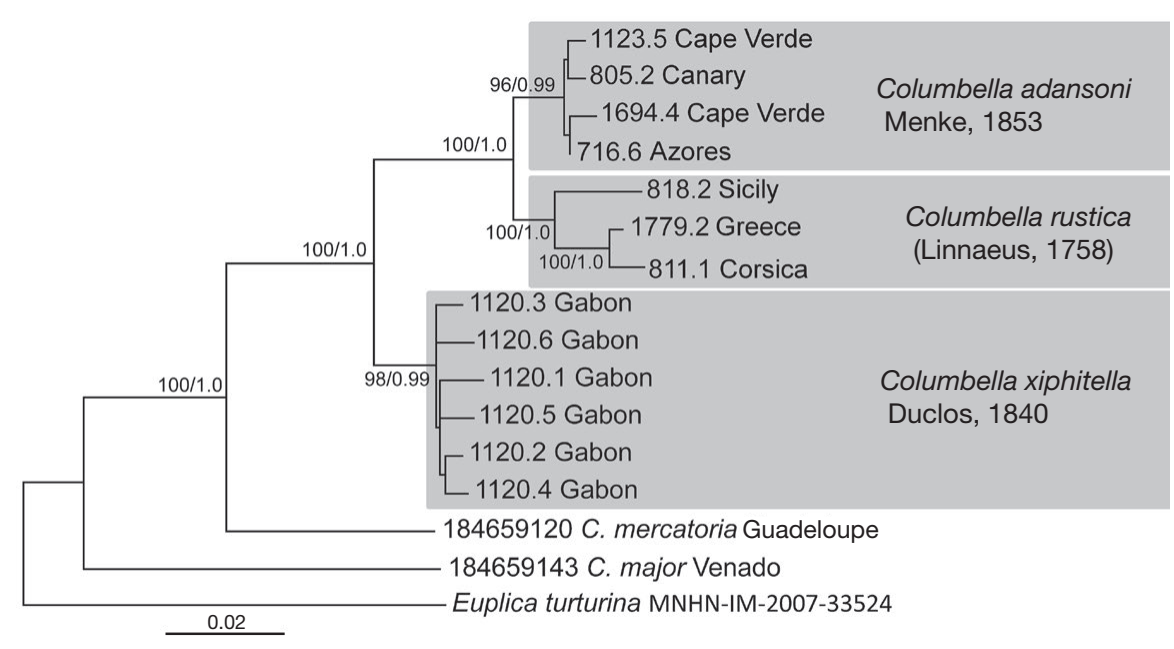

FIG. 5. - ML tree based on the combined COI-16S dataset (HKY $+\mathrm{I}+\mathrm{G}$ model of evolution). Numbers at nodes indicate the support by BI Bps (107 generations and $25 \%$ burn in) and ML bs (1000 replicates). 
All phylogenetic analyses (ML and $\mathrm{BI}$ ) of the single gene (16S, COI: including shorter sequences) and of the combined datasets of the eastern Atlantic/Mediterranean Columbella retrieved the same topology, with the sequences corresponding to the species hypotheses of ABGD grouped as reciprocally monophyletic clades with high bootstrap values and posterior probabilities (ML bootstrap $\geq 96 \%$, BI support $\geq 0.99$ : Figs 3-5). In all trees, $C$. adansoni was restricted to the Macaronesian specimens, C. rustica to the Mediterranean specimens, and the African specimens comprised a third lineage. The pair including $C$. adansonil C. rustica (ML bootstrap $\geq 98 \%$, BI support $\geq 0.99$ ) was the sister to the African species, which according to the phylogenetic patterns from COI and 16S, included samples from Ghana, São Tomé, Gabon and Angola. Autapomorphic (diagnostic) nucleotides were scored for each species by comparing their COI sequences and are reported in Table 3 .

\section{SYSTEMATICS}

Family Columbellidae Swainson, 1840 Genus Columbella Lamarck, 1799

TYPE SPECIES. - Voluta mercatoria Linnaeus, 1758, by monotypy.

\section{REMARK}

The list of available names for eastern Atlantic Columbella is rather long. According to Tryon (1883) and updated with more recent works (e.g., Moolenbeek \& Hoenselaar 1991; Bouchet \& Gofas 2010; Monsecour \& Gofas 2010a, b), we have scored 26 nominal taxa (some under the incorrect subsequent spelling Colombella) referable to the Columbella rustica complex. All nominal taxa with an explicit Macaronesian type locality can be ascribed to $C$. adansoni: Columbella adansoni Menke, 1853, C. rufa Menke, 1853, C. rustica var. azorica Drouët, 1858, C. striata var. minor Dautzenberg, 1900. All nominal taxa with an explicit type locality from Senegal to Mediterranean (where a single species is known) and/or with a paucispiral protoconch are easily ascribed to Columbella rustica. This is the case of Voluta rustica Linnaeus, 1758, C. rustica var. elongata Philippi, 1836, C. spongiarum Duclos, 1840, C. striata Duclos, 1840, C. fustigata Kiener, 1841, C. striata Duclos in Chenu, 1846, C. simpronia Duclos in Chenu, 1846, C. rustica var. cuneatiformis Pallary, 1900, C. rustica var. lutea Pallary, 1900, C. rustica var. minor Pallary, 1900, C. rustica var. obesula Pallary, 1900. The other synonymies currently implemented in WoRMS for this complex are almost all accepted (where necessary by correcting or imposing Mediterranean as type locality, see below) since they maintain stability of current usage, with two exceptions: C. xiphitella Duclos, 1840 and C. nucleus Kiener, 1841. Among ten potential syntypes of the latter at MHNG, eight have eroded apices, while two have protoconchs partly eroded but clearly multispiral; if we imposed a Macaronesia type locality, this would make $C$. nucleus a senior synonym of $C$. adansoni (which has been the accepted valid name for the Macaronesian species for the last 25 years: Moolenbeek \& Hoenselaar, 1991). The same holds for C. xiphitella Duclos, 1840: two of the 16 syntypes at MNHN have clearly multispiral protoconchs, the locality indicated ("Californie") is clearly erroneous, and imposing a Macaronesian type locality would make $C$. xiphitella also a senior synonym of C. adansoni. Therefore, to preserve nomenclatural stability in this group, we have decided to impose as first reviewers, "Gabon" as type locality to both C. xiphitella Duclos, 1840 and C. nucleus Kiener, 1841.

Columbella rustica (Linnaeus, 1758) (Figs 6A, B; 7A-D; 8C)

Voluta rustica Linnaeus, 1758: 731.

Columbella reticulata Lamarck, 1822: 295.

Columbella gualteriana Risso, 1826: 206, n533.

Columbella rustica var. elongata Philippi, 1836: 228.

Colombella tumida Duclos, 1840: pl. 1, figs 13, 14.

Colombella spongiarum Duclos, 1840: pl. 3, figs 13-16.

Columbella striata Duclos, 1840: pl. 6, figs 5-8 (not Menke 1829).

Columbella ambigua Kiener, 1840: 11, pl. 2, fig. 3 [note: plate issued in 1840].

Columbella fustigata Kiener, 1841: 20-21, pl. 5, fig. 3.

Columbella modesta Kiener, 1841: 22, pl. 11, fig. 2.

Colombella aureola Duclos in Chenu, 1846: pl. 6, figs 17, 18.

Colombella simpronia Duclos in Chenu, 1846: pl. 15, figs 19, 20.

Colombella vestalia Duclos in Chenu, 1846: pl. 15, figs 15, 16.

Colombella zulmis Duclos in Chenu, 1848: pl. 24, figs 21, 22.

Columbella rustica var. cuneatiformis Pallary, 1900: 278, pl. 6, fig. 17.

Columbella rustica var. lutea Pallary, 1900: 278.

Columbella rustica var. minor Pallary, 1900: 277.

Columbella rustica var. obesula Pallary, 1900: 278, pl. 6, fig. 18.

TYPe MATERIAL. - Voluta rustica: 6 sh in the Linnaean Society (LSL.348 [Dance label image ref: P-Z 0010728] http://linneanonline.org/17388/). — Type locality: Mediterranean.

Columbella reticulata: 5 probable syntypes MHNG-MOLL-92487. Type locality: Mediterranean (imposed herein, ICZN 1999: rec. 76A.1.4).

Columbella gualteriana: lectotype (Arnaud 1978) MNHNIM-2000-6899. — Type locality: Mediterranean (imposed herein, ICZN 1999: rec. 76A.1.4).

Columbella rustica var. elongata: lectotype ZMB 13.994, 2 paralectotypes ZMB 112.717. - Type locality: Palermo (Sicily).

Colombella tumida: 2 syntypes MNHN-IM-2000-6373. - Type locality: "China", erroneous, corrected to Mediterranean (ICZN 1999: rec. 76.A.2).

Colombella spongiarum: 2 syntypes, MNHN-IM-2000-6385. Type locality: Senegal.

Columbella striata: syntypes, 15 sh without locality label 
MNHN-IM-2000-6381, and 5 sh from Senegal MNHNIM-2000-6382. - Type locality: Senegal.

Columbella ambigua: 6 syntypes MNHN-IM-2000-6935. - Type locality: "Asia", erroneous, corrected to Mediterranean (ICZN 1999: rec. 76.A.2).

Columbella fustigata: 7 syntypes MNHN-IM-2000-6904. - Type locality: "Iles Saintes" (Îles des Saintes, Antilles), erroneous, corrected to Mediterranean (ICZN 1999: rec. 76.A.2).

Columbella modesta: MHNG-MOLL-95504 (5 probably not types from Delessert coll. and not "Mus coll" as in description). - Type locality: Mediterranean (imposed herein, ICZN 1999: rec. 76A.1.4). Colombella aureola: 1 shell MNHN-IM-2000-6346). - Type locality: "Californie", erroneous, corrected to Mediterranean (ICZN 1999: rec. 76.A.2)

Colombella simpronia: 4 syntypes MNHN-IM-2000-6389. — Type locality: Mediterranean.

Colombella vestalia: Not found, not present in MNHN. - Type locality: Mediterranean (imposed herein, ICZN 1999: rec. 76A.1.4). Colombella zulmis: MNHN-IM-2000-9609. - Type locality: "China", erroneous, corrected to Mediterranean (ICZN 1999: rec. 76.A.2). Columbella rustica var. cuneatiformis: not found at MNHN. - Type locality: Oran, Algeria.

Columbella rustica var. luted: not found at MNHN. - Type locality: Oran, Algeria.

Columbella rustica var. minor: not found at MNHN. - Type locality: Oran, Algeria.

Columbella rustica var. obesula: not found at MNHN. - Type locality: Oran, Algeria.

Distribution. - According to the present data, Columbella rustica ranges throughout the entire Mediterranean Sea, and extends in the Atlantic South to Senegal, and North to Portugal.

DiAGNOSIS. - Shell of medium size for the family 12-20 mm long, biconic/strombiform.

Protoconch of 1.5-1.6 smooth, convex whorls; protoconch-teleoconch boundary marked by a slightly opisthocline scar.

Teleoconch of 7-9 almost straight-sided whorls, penultimate whorl slightly convex, body whorl rounded and inflated, about $2 / 3$ to $3 / 4$ shell length.

Sculpture of nodulose axial ridges on the first whorls, fading after 2-3 whorls, and very weak, irregular spiral striae. Aperture narrow, elongate and sinuous.

Outer lip angulate posteriorly in some, thickened, especially medially, with 13-16 denticles, and rust coloured markings between denticles. Columellar wall with two weak ridges medially; parietal wall with 5-7 denticles anteriorly, sometimes with rust coloured markings between. Siphonal canal open.

Colour very variable, with white-whitish background and yellow, orange, brown, grey or black irregular spots, sometimes arranged into axial flames or sinuous bands.

Periostracum thin, brown.

Animal with whitish to yellowish background and tawny-orange spots, very dense on propodium, head and mantle; tip of cephalic tentacles white; siphon grey. Radula rachiglossate, with central tooth reduced to a slightly arched plate with no cusps. One pair of massive lateral teeth with a small, basal, outer cusp and a tall, sinuous inner primary cusp with three secondary cusps along the posterior edge: a narrow, pointed distal cusp, a flat central cusp slightly enlarged at the base, and a quadrangular and apically curved basal cusp.

\section{REMARKS}

We correct herein (ICZN 1999: rec. 76.A.2) to "Mediterranean" the evidently erroneous localities indicated for $\mathrm{Co}$ lombella tumida, Columbella ambigua, Columbella fustigata, Colombella aurola, Colombella zulmis; and impose (ICZN 1999: rec. 76A.1.4) "Mediterranean" for Colombella vestalia,
Columbella modesta, Columbella reticulata, Columbella gualteriana. The five possible syntypes of Columbella reticulata Lamarck (MHNG-MOLL-92487, ex Delessert collection) bear "Bresil" as locality, quite probably a posthumous erroneous labelling.

Very variable in coloration, but also in size, with some populations of very small adult size $(12 \mathrm{~mm})$ and others attaining much larger length $(20 \mathrm{~mm})$.

Franc (1943) described the egg capsules and embryos of C. rustica: the capsules contained 39-57 eggs, 250-280 $\mu \mathrm{m}$ in diameter, of which most were nurse eggs to nourish the 1-2 developing embryos (shell length at hatching 660-850 $\mu \mathrm{m}$ ). See also Bandel (1975) for a description of the protoconch in specimens from Banyuls. Pelorce \& Boyer (2005: fig. 11) described samples from Central Senegal as 10-14 mm long, with paucispiral protoconch of 1.5-2 whorls, the animal milky white or cream with amber-brown speckles, which matches remarkably the appearance of Mediterranean samples.

As already noticed by Moolenbeek \& Hoenselaar (1991), Columbella striata Duclos (originally described from Senegal) is a junior homonym of Columbella striata Menke, 1829 and therefore is not usable as the valid name for any species. In Senegal two distinct protoconch types have been sometimes cited and interpreted as multispiral and paucispiral, respectively (Thorsson 2003). However, based on Oliverio (1995), Rolán \& Ryall (1999), Hernández \& Boyer (2005) and Pelorce \& Boyer (2005), all intact protoconchs of Columbella from Morocco to Mauritania, including Senegal, are paucispiral. Unfortunately, material from Senegal or Mauritania properly fixed for DNA extraction was not available for this study and the actual identity of the Columbella from this area could not be unequivocally assessed herein.

Three autapomorphic positions were scored in the COI sequences: 238 [C], 310 [T], 447 [G].

\section{Columbella adansoni Menke, 1853 \\ (Figs 6C, D; 7G-H; 8A)}

Columbella Adansoni [sic] Menke, 1853: 74, 75.

Columbella rufa Menke, 1853: 75.

Columbella rustica var. azorica Drouët, 1858: 169.

Columbella striata var. minor Dautzenberg, 1900: 183.

TYPE MATERIAL. - Columbella adansoni: lectotype (Moolenbeek \& Hoenselaar 1991) SMF. — Type locality: Cape Verde Islands.

Columbella rufa: lectotype (Moolenbeek \& Hoenselaar, 1991) SMF. - Type locality: Cape Verde Islands.

Columbella rustica var. azorica: unknown (Moolenbeek \& Hoenselaar, 1991). — Type locality: Azores.

Columbella striata var. minor. - Type locality: Ilhéu Branco (Cape Verde Islands).

Distribution. - According to the data presented herein, Columbella adansoni ranges throughout Macaronesia, and is not present in continental African waters.

DiAGNOSIS. - Shell of medium size for the family, 16-25 mm long, biconic/strombiform. 

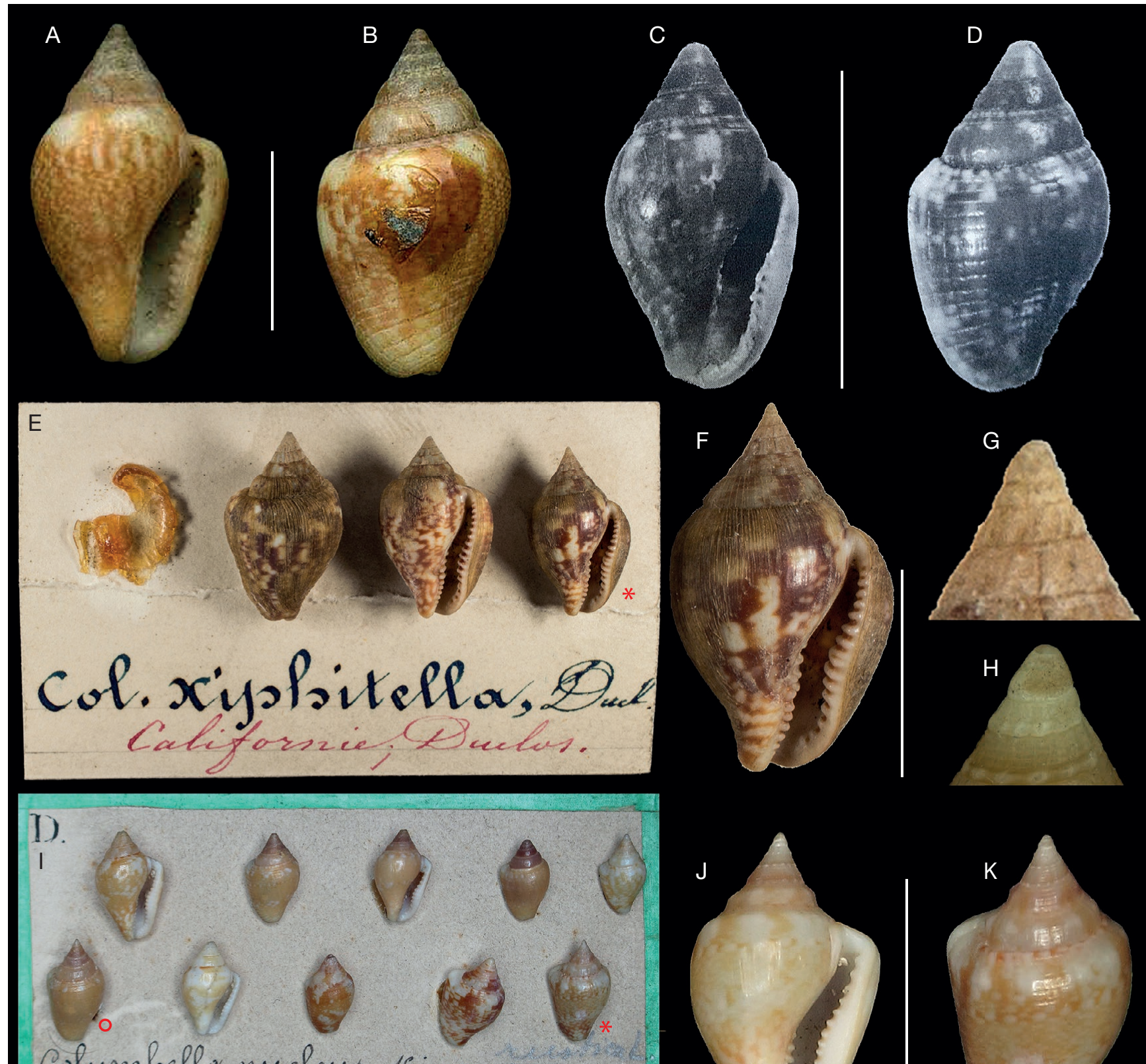

Columbella nucleus, kiener
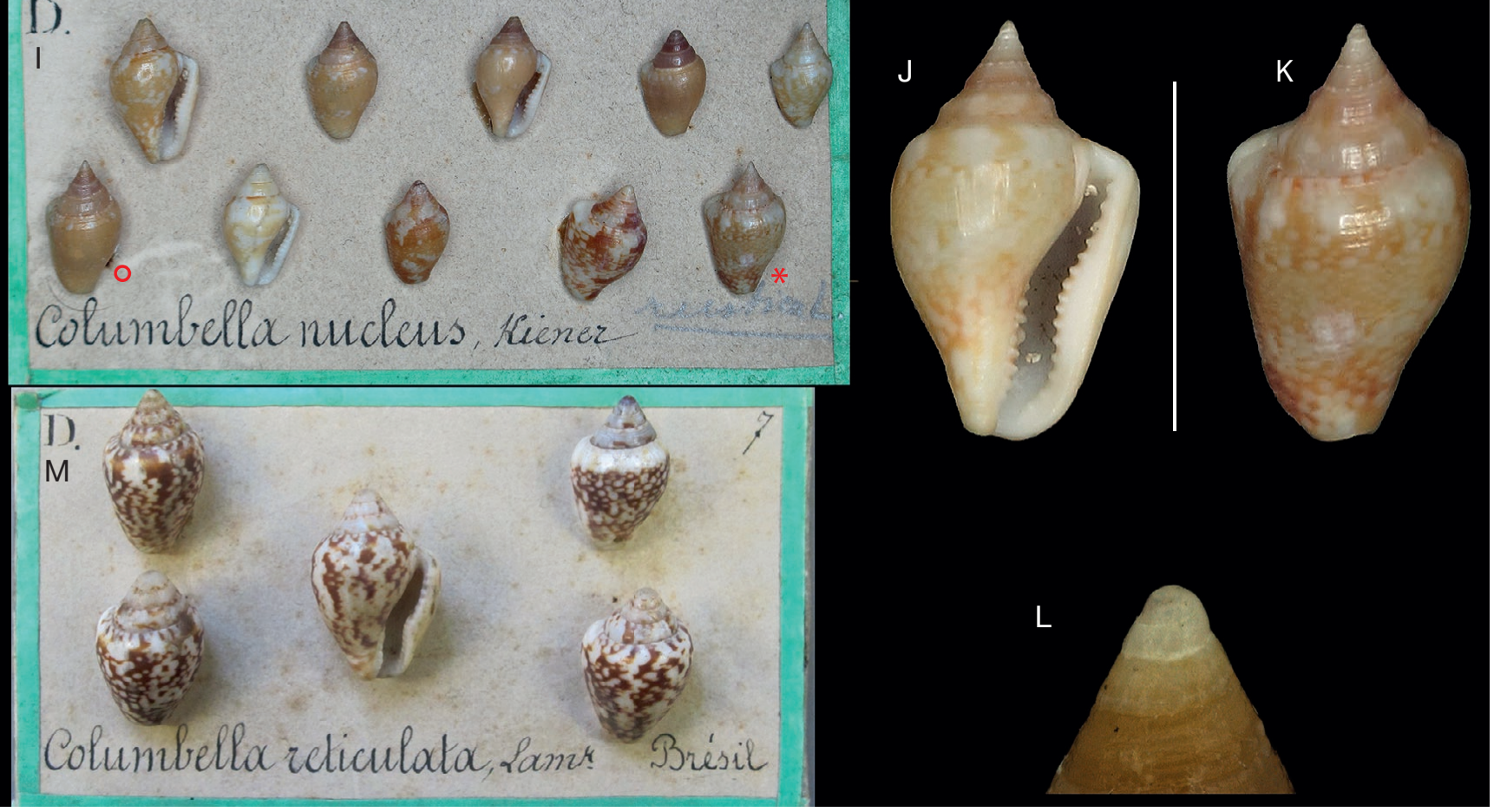

FIG. 6. - Columbella spp. types: A, B, Columbella rustica (Linnaeus, 1758), syntype of Voluta rustica (LSL.348), Mediterranean (permission of The Linnean Society of London); C, D, Columbela adansoni Menke, 1853, lectotype SMF, Cape Verde (after Moolenbeek \& Hoenselaar 1991, figs 1, 2); E-G, Columbella xiphitella Duclos, 1840, lectotype (F, G) and paralectotypes (E) from lot MNHN-IM-2000-9599, Gabon; H-L, Columbella xiphitella, lectotype (H, J, K) and paralectotypes (I, L) of C. nucleus Kiener, 1841 from lot MHNG-MOLL-95502. Symbols: *, the selected lectotypes; O, the paralectotype with close-up of the protoconch (L). Scale bars: $10 \mathrm{~mm}$; G, H, L, not to scale. 


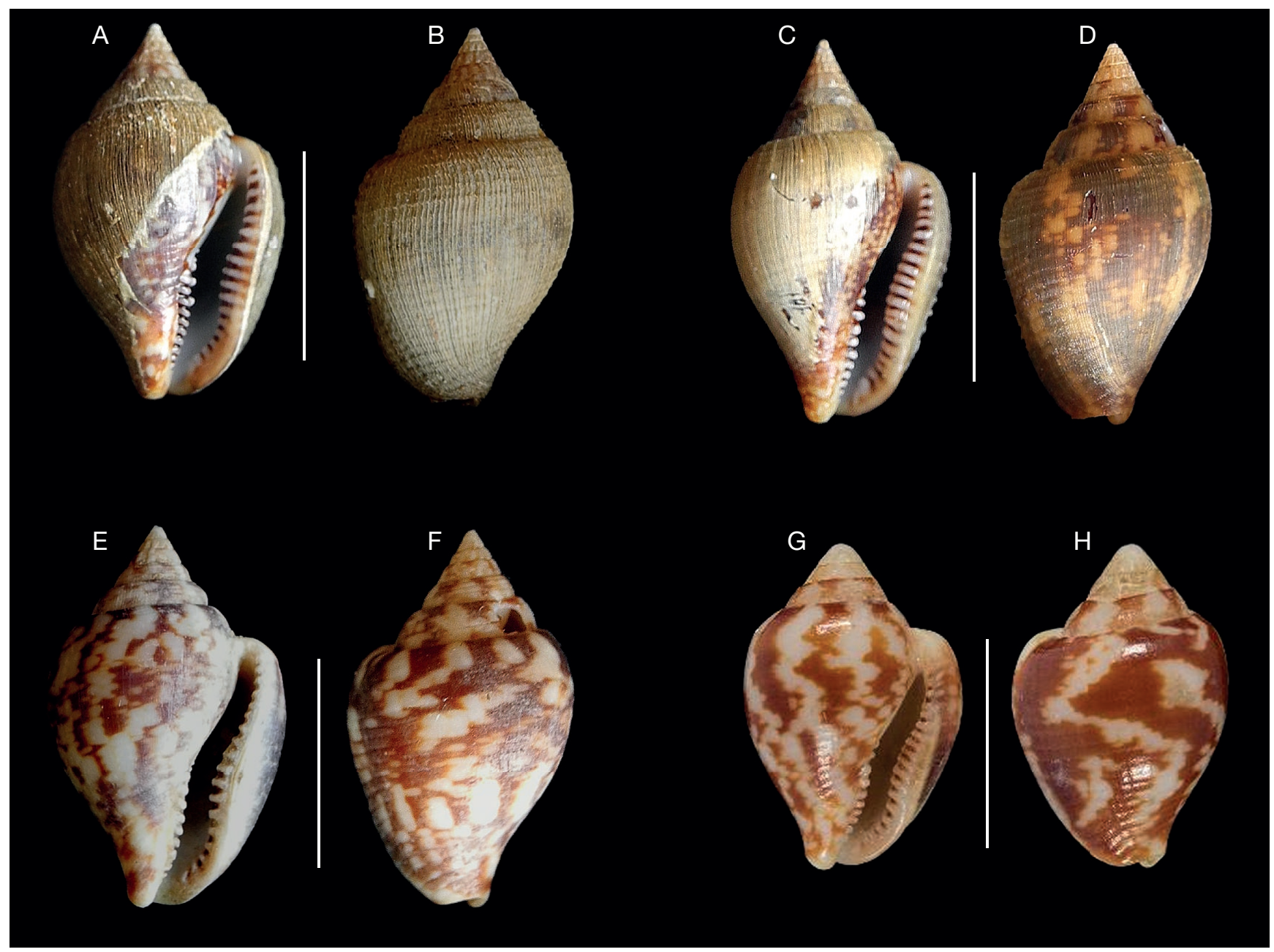

FIG. 7. - Columbella xiphitella Duclos, 1840 Gabon: A, B, MNHN IM-2000-32498; C, D, MNHN IM-2000-32498; E, F, BAU 1120.7; G, H, paralectotype from lot MNHN-IM-2000-9599. Scale bars: $10 \mathrm{~mm}$.

Protoconch of 2.5-2.6 convex whorls, entirely covered by densely spaced microgranules; embryonic shell (protoconch I) of 0.8 0.9 whorls, and larval shell (protoconch II) of 1.6-1.7 whorls; protoconch-teleoconch boundary marked by a sinusigera scar. Teleoconch of 7-9 almost straight-sided whorls, penultimate whorl slightly convex, body whorl rounded and inflated, about $2 / 3$ to $3 / 4$ shell length.

Sculpture of nodulose axial ridges on the first whorls, fading after 2-3 whorls, and very weak, irregular spiral striae. Aperture narrow, elongate and sinuous.

Outer lip angulate posteriorly in some, thickened, especially medially, with 13-16 denticles, and rust coloured markings between denticles. Columellar wall with two weak ridges medially; parietal wall with 5-7 denticles anteriorly, and rust coloured markings between. Siphonal canal open.

Colour very variable, with white-whitish background and yellow, orange, brown, grey or black irregular spots, sometimes arranged into axial flames or sinuous bands. Periostracum thin, brown.

Animal yellowish with tawny-orange spots, very dense on propodium, head and mantle; tip of cephalic tentacles white, siphon grey. Radula rachiglossate, with central tooth reduced to a slightly arched plate with no cusps. One pair of massive lateral teeth with a small, basal, outer cusp and a tall, sinuous inner primary cusp with three secondary cusps along the posterior edge: a narrow, pointed distal cusp, a flat central cusp slightly enlarged at the base, and a quadrangular and apically curved basal cusp.

\section{REMARKS}

Knudsen (1995) summarized his own (Knudsen 1950) and Gunnar Thorson's (unpublished) notes on the egg capsules of $C$. adansoni from Cape Verde Islands and Canary Islands, respectively. The egg capsules contained 39-73 eggs, c. $200 \mu \mathrm{m}$ in diameter, developing into pelagic larvae attaining at metamorphosis $450 \mu \mathrm{m}$ shell width (1000 $\mu \mathrm{m}$ length).

Seven autapomorphic positions were scored in the COI sequences: $61[\mathrm{G}], 91[\mathrm{G}], 160[\mathrm{C}], 181[\mathrm{~T}], 352[\mathrm{C}]$, $549[\mathrm{~A}], 586[\mathrm{~T}]$.

\section{Columbella xiphitella Duclos, 1840}

(Figs 6E-L; 7A-H; 8B; 9A, B)

Colombella xiphitella Duclos, 1840: pl. 9, figs 13, 14.

Columbella nucleus Kiener, 1841: 14-15, pl. 3, fig. 4. 


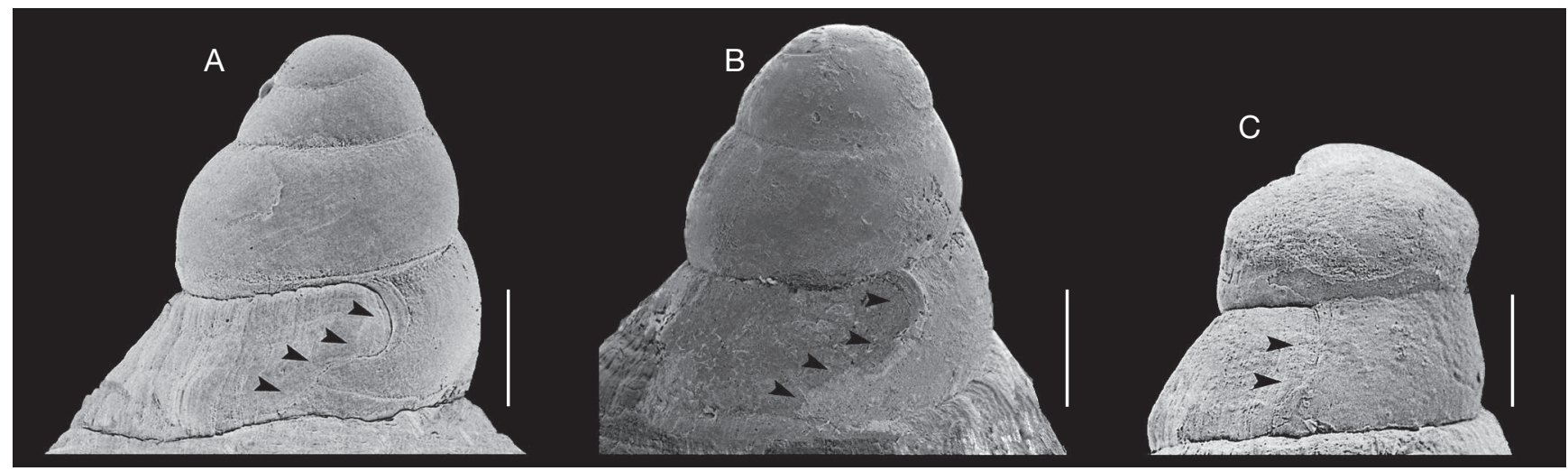

FIG. 8. - Protoconchs of Columbella spp.: A, Columbella adansoni Menke, 1853, Tenerife Is., Canary Islands; B, Columbella xiphitella Duclos, 1840, Miemia, Ghana; C, Columbella rustica (Linnaeus, 1758), San Domino Is., Italy. Arrows indicate the protoconch-teleoconch boundary. Scale bars: 100 um.
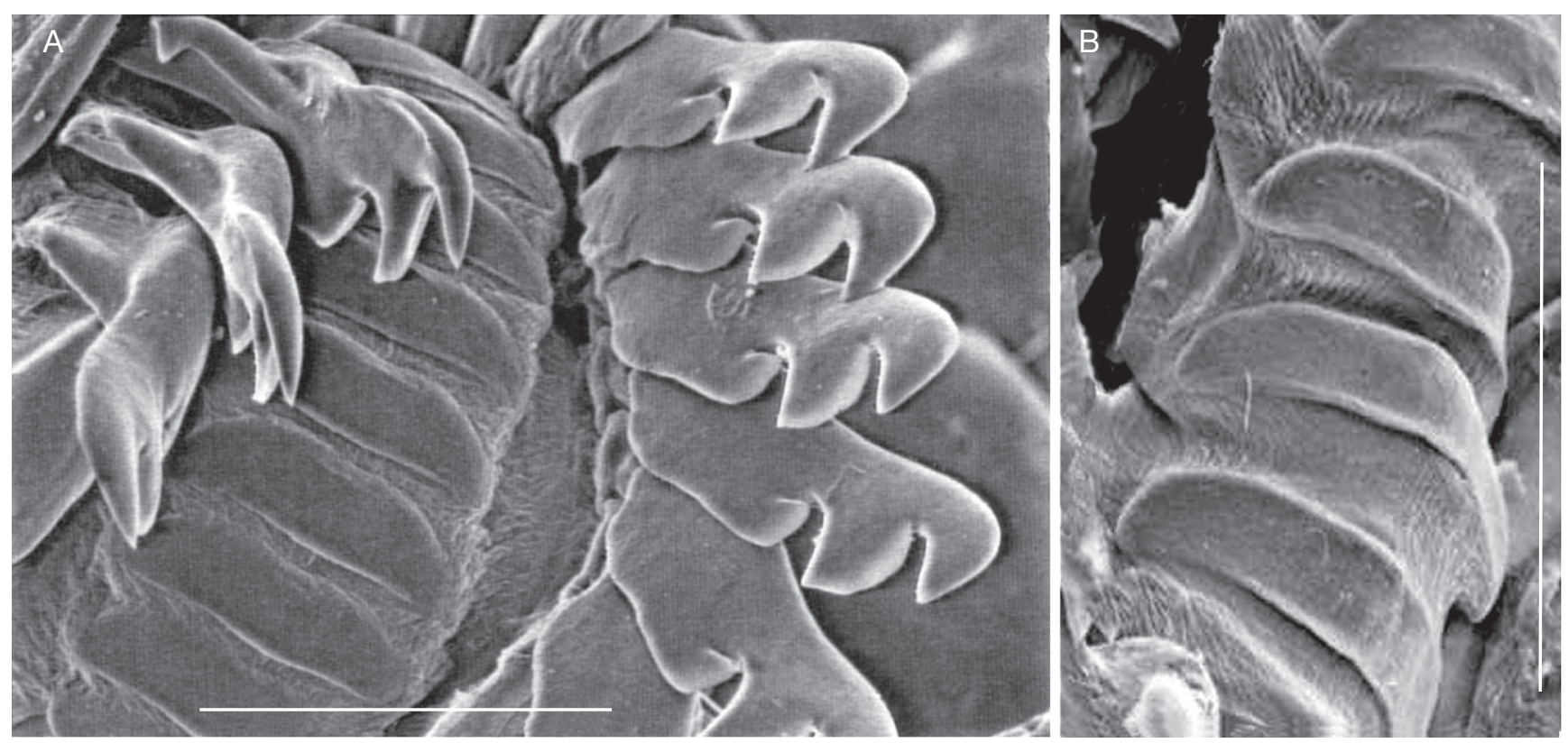

FIG. 9. - Radula of Columbella xiphitella Duclos, 1840: A, Miemia, Ghana; B, Lagoa Azul, São Tomé, detail of the rachidian. Scale bars: 100 $\mu$ m.

TYPE MATERIAL. - Colombella xiphitella: lectotype (here designated: Fig. 6F, G) and 11 paralectotypes MNHN-IM-2000-9599, 4 paralectotypes MNHN-IM-2000-9598. — Type locality: "Californie", erroneous, corrected to Gabon (ICZN 1999: rec. 76.A.2).

Columbella nucleus: MHNG-MOLL-95502 lectotype (here selected: Fig. $6 \mathrm{H}, \mathrm{J}, \mathrm{K}$ ) and 9 paralectoypes (from Delessert collection). - Type locality: Gabon (imposed herein, ICZN 1999: rec. 76A.1.4).

DisTRIBUTION. - According to the material examined genetically herein, Columbella xiphitella ranges along West African coasts from Ghana to Angola, including Sáo Tomé and Principe.

DiAGNOSIS. - Shell of medium size for the family, 10-18 mm long, biconic/strombiform.

Protoconch of 2.5-2.6 convex whorls, entirely covered by densely spaced microgranules; embryonic shell (protoconch I) of 0.8 whorls, and larval shell (protoconch II) of 1.7 whorls; protoconch-teleoconch boundary marked by a sinusigera scar.
Teleoconch of 7-9 almost straight-sided whorls, penultimate whorl slightly convex, body whorl rounded and inflated, about $3 / 4$ shell length. Sculpture of nodulose axial ridges on the first whorls, fading after 2-3 whorls, and very weak, irregular spiral striae. Aperture narrow, elongate and sinuous.

Outer lip angulate posteriorly in some, thickened, especially medially, with 14-19 strong denticles, and rust coloured markings between denticles. Columellar wall with two weak ridges medially; parietal wall with 5-8 strong denticles anteriorly, usually with rust coloured markings between. Siphonal canal open.

Colour very variable, with white-whitish background and yellow, orange, brown, grey or black irregular spots, sometimes arranged into axial flames or sinuous bands. Periostracum thin, brown.

Animal observed only in alcohol preserved specimens: whitish background and dark brown to dark tawny spots, dense on propodium and head, very dense on mantle; tip of cephalic tentacles white, siphon dark grey. Radula rachiglossate, with central tooth reduced to a slightly arched plate with no cusps. One pair of massive lateral teeth with a small, basal, outer cusp and a tall, sinuous inner primary 
TABLE 4. - COI sequences of worldwide columbellids, with the ABGD group assignation (alternate grey/white lines, according to ABGD groups numbers), voucher ID (or GenBank accession number), a-priori morphological identification, a-posteriori MOTU assignation.

\begin{tabular}{|c|c|c|c|}
\hline ABGD group & Voucher ID & a priori morphological identification & a posteriori MOTU assignation \\
\hline 1 & IM-2007-33580 & Aesopus cumingii (Duclos, 1846) & A. cumingii \\
\hline 1 & IM-2007-33581 & Aesopus cumingii & A. cumingii \\
\hline 2 & KF643896.1 & Amphissa columbiana (Dall, 1916) & A. aff. columbiana \\
\hline 2 & KF644010.1 & Amphissa columbiana & A. aff. columbiana \\
\hline 2 & KF644101.1 & Amphissa columbiana & A. aff. columbiana \\
\hline 2 & KF643694.1 & Amphissa versicolor (Dall, 1871) & A. aff. columbiana \\
\hline 3 & KF644285.1 & Amphissa reticulata (Dall, 1916) & A. reticulata \\
\hline 4 & KF643489.1 & Alia carinata (Hinds, 1844) & A. carinata \\
\hline 4 & KF643493.1 & Alia carinata & A. carinata \\
\hline 4 & KF643566.1 & Alia carinata & A. carinata \\
\hline 4 & KF643846.1 & Alia carinata & A. carinata \\
\hline 4 & KF643937.1 & Alia carinata & A. carinata \\
\hline 4 & KF644175.1 & Alia carinata & A. carinata \\
\hline 4 & KF644247.1 & Alia carinata & A. carinata \\
\hline 4 & KF644276.1 & Alia carinata & A. carinata \\
\hline 4 & KF643354.1 & Alia carinata & A. carinata \\
\hline 5 & IM-2009-11313 & Anachis sp. & Anachis sp. \\
\hline 6 & BAU 710_7 & Columbella adansoni Menke, 1853 & C. adansoni \\
\hline 6 & BAU 726_7 & Columbella adansoni & C. adansoni \\
\hline 6 & BAU 741_11 & Columbella adansoni & C. adansoni \\
\hline 7 & BAU 1120_1 & Columbella adansoni & C. xiphitella \\
\hline 7 & BAU 1120_2 & Columbella adansoni & C. xiphitella \\
\hline 7 & BAU1120_3 & Columbella adansoni & C. xiphitella \\
\hline 8 & BAU 817_1 & Columbella rustica (Linnaeus, 1758) & C. rustica \\
\hline 8 & BAU 818_5 & Columbella rustica & C. rustica \\
\hline 8 & BAU 821_2 & Columbella rustica & C. rustica \\
\hline 9 & IM-2009-18927 & columbellid indet. & columbellid indet. \\
\hline 9 & IM-2007-35775 & columbellid indet. & columbellid indet. \\
\hline 10 & IM-2007-35599 & columbellid indet. & columbellid indet. \\
\hline 11 & IM-2007-33570 & columbellid indet. & columbellid indet. \\
\hline 12 & IM-2007-33521 & Euplica borealis (Pilsbry, 1904) & E. borealis \\
\hline 13 & IM-2007-33515 & Euplica scripta (Lamarck, 1822) & E. scripta \\
\hline 14 & JN052985.1 & Euplica scripta & E. scripta \\
\hline 15 & JN052986.1 & Euplica scripta & E. scripta \\
\hline 15 & JN052987.1 & Euplica scripta & E. scripta \\
\hline 15 & HQ834054.1 & Euplica scripta & E. scripta \\
\hline 16 & IM-2007-33519 & Euplica turturina (Lamarck, 1822) & E. turturina \\
\hline 16 & IM-2007-33522 & Euplica turturina & E. turturina \\
\hline 16 & IM-2007-33524 & Euplica turturina & E. turturina \\
\hline 16 & IM-2007-33539 & Euplica turturina & E. turturina \\
\hline 16 & JQ950207.1 & Euplica turturina & E. turturina \\
\hline 17 & IM-2007-33537 & Euplica varians (Sowerby, 1832) & E. varians \\
\hline 17 & IM-2007-33583 & Euplica varians & E. varians \\
\hline 18 & IM-2007-33493 & Graphicomassa albina (Kiener, 1841) & G. adiostina (Duclos, 1840) \\
\hline 18 & IM-2007-33494 & Graphicomassa albina & G. adiostina \\
\hline 19 & IM-2007-33514 & Graphicomassa ligula (Duclos, 1835) & G. ligula \\
\hline 19 & IM-2007-33517 & Graphicomassa ligula & G. ligula \\
\hline 19 & IM-2007-33523 & Graphicomassa ligula & G. ligula \\
\hline 19 & IM-2007-33534 & Graphicomassa ligula & G. ligula \\
\hline 19 & IM-2007-33542 & Graphicomassa ligula & G. ligula \\
\hline 19 & JQ950206.1 & Graphicomassa ligula as Mitrella ligula (Duclos, 1840) & G. ligula \\
\hline 20 & IM-2007-35779 & Indomitrella cf. conspersa (Gaskoin, 1851) & I. cf. conspersa \\
\hline 21 & IM-2007-33532 & Indomitrella puella (Sowerby, 1844) & I. puella \\
\hline 22 & IM-2007-33548 & Indomitrella schepmani K. Monsecour \& D. Monsecour, 2007 & I. schepmani \\
\hline 22 & IM-2007-35594 & Indomitrella schepmani & I. schepmani \\
\hline 23 & HM180683.1 & Mitrella bicincta (Gould, 1860) & M. aff. bicincta \\
\hline 23 & HM180684.1 & Mitrella bicincta & M. aff. bicincta \\
\hline 23 & HM180685.1 & Mitrella bicincta & M. aff. bicincta \\
\hline 23 & HM180687.1 & Mitrella bicincta & M. aff. bicincta \\
\hline 23 & HM180688.1 & Mitrella bicincta & M. aff. bicincta \\
\hline 23 & HM180690.1 & Mitrella bicincta & M. aff. bicincta \\
\hline 23 & HM180691.1 & Mitrella bicincta & M. aff. bicincta \\
\hline 23 & HM180692.1 & Mitrella bicincta & M. aff. bicincta \\
\hline 23 & JN053028.1 & Mitrella burchardi (Dunker, 1877) & M. aff. bicincta \\
\hline 23 & HQ834098.1 & Mitrella burchardi & M. aff. bicincta \\
\hline 24 & JN052988.1 & Mitrella bicincta (Gould, 1860) & M. bicincta \\
\hline 24 & JN052989.1 & Mitrella bicincta & M. bicincta \\
\hline 24 & JN052990.1 & Mitrella bicincta & M. bicincta \\
\hline 24 & JN052991.1 & Mitrella bicincta & M. bicincta \\
\hline
\end{tabular}


Table 4. - Continuation.

\begin{tabular}{|c|c|c|c|}
\hline ABGD group & Voucher ID & a priori morphological identification & a posteriori MOTU assignation \\
\hline 24 & HQ834055.1 & Mitrella bicincta (Gould, 1860) & M. bicincta \\
\hline 24 & HM180686.1 & Mitrella bicincta & M. bicincta \\
\hline 24 & HM180689.1 & Mitrella bicincta & M. bicincta \\
\hline 25 & IM-2007-30282 & Mitrella cf. philia (Duclos, 1846) & M. cf. philia \\
\hline 26 & IM-2007-35498 & Mitrella essingtonensis (Reeve, 1859) & M. essingtonensis \\
\hline 27 & IM-2007-33485 & Metanachis jaspidea (Sowerby, 1844) & M. jaspidea \\
\hline 27 & IM-2007-33529 & Metanachis jaspidea & M. jaspidea \\
\hline 27 & IM-2007-33585 & Metanachis jaspidea & M. jaspidea \\
\hline 28 & IM-2007-33490 & Mitrella moleculina (Duclos, 1835) & M. moleculina \\
\hline 29 & IM-2007-33504 & Mitrella nympha (Kiener, 1841) & M. nympha \\
\hline 29 & IM-2007-33565 & Mitrella nympha & M. nympha \\
\hline 30 & IM-2007-35750 & columbellid indet. & Mitrella sp. \\
\hline 30 & IM-2007-35749 & Mitrella cf. moleculina (Duclos, 1840) & Mitrella sp. \\
\hline 30 & IM-2007-35495 & Mitrella sp. & Mitrella sp. \\
\hline 31 & KF643804.1 & Mitrella cf. tuberosa (Carpenter, 1865) & Mitrella sp. \\
\hline 32 & IM-2007-33582 & Mitrella sp. & Mitrella sp. \\
\hline 33 & IM-2007-35626 & Mitrella sp. & Mitrella sp. \\
\hline 34 & IM-2013-20589 & Nassarina metabrunnea (Dall \& Simpson, 1901) & N. metabrunnea \\
\hline 35 & IM-2007-36625 & Pyrene flava (Bruguière, 1789) & P. flava \\
\hline 35 & IM-2007-36760 & Pyrene flava & P. flava \\
\hline 35 & IM-2007-36685 & Pyrene flava & P. flava \\
\hline 36 & IM-2007-33560 & Pyrene punctata (Bruguiere, 1789) & P. punctata \\
\hline 36 & IM-2007-33578 & Pyrene punctata & P. punctata \\
\hline 37 & HQ834097.1 & Pseudamycla sp. & Pseudamycla sp. \\
\hline 38 & IM-2007-39377 & columbellid indet. & S. cf. kanamaruana A \\
\hline 38 & IM-2007-32142 & Sulcomitrella cf. kanamaruana (Kuroda, 1953) & S. cf. kanamaruana A \\
\hline 38 & IM-2007-33555 & Sulcomitrella sp. & S. cf. kanamaruana A \\
\hline 39 & IM-2009-11298 & Sulcomitrella cf. kanamaruana (Kuroda, 1953) & S. cf. kanamaruana B \\
\hline 39 & IM-2009-11301 & Sulcomitrella cf. kanamaruana & S. cf. kanamaruana B \\
\hline 39 & IM-2007-32150 & Sulcomitrella cf. kanamaruana & S. cf. kanamaruana B \\
\hline 39 & IM-2007-33479 & Sulcomitrella cf. kanamaruana & S. cf. kanamaruana B \\
\hline 39 & IM-2007-33482 & Sulcomitrella cf. kanamaruana & S. cf. kanamaruana B \\
\hline 39 & IM-2007-33574 & Sulcomitrella cf. kanamaruana & S. cf. kanamaruana B \\
\hline 39 & IM-2007-33575 & Sulcomitrella cf. kanamaruana & S. cf. kanamaruana B \\
\hline 39 & IM-2007-33540 & Sulcomitrella circumstriata (Schepman, 1911) & S. cf. kanamaruana B \\
\hline 39 & IM-2007-36339 & Sulcomitrella circumstriata & S. cf. kanamaruana B \\
\hline 40 & IM-2007-35773 & Sulcomitrella cf.. monodonta (Habe, 1958) & S. cf.. monodonta A \\
\hline 41 & IM-2009-11304 & Sulcomitrella monodonta (Habe, 1958) & S. cf.. monodonta B \\
\hline 42 & IM-2007-33551 & Sulcomitrella circumstriata (Schepman, 1911) & S. circumstriata \\
\hline 42 & IM-2007-33552 & Sulcomitrella circumstriata & S. circumstriata \\
\hline 43 & IM-2007-30246 & Zafra cf. pumila (Dunker, 1858) & Z. cf. pumila \\
\hline 44 & IM-2007-33480 & Zafrona isomella (Duclos, 1840) & Z. isomella \\
\hline 45 & IM-2007-30355 & Zafra pumila (Dunker, 1858) & Z. pumila \\
\hline 46 & IM-2007-33535 & Metanachis laingensis Sleurs, 1985 & Mitrella sp. \\
\hline 46 & IM-2007-33536 & Mitrella cf. alizonae (Melvill \& Standen, 1901) & Mitrella sp. \\
\hline 46 & IM-2007-33488 & Mitrella chinoi Monsecour \& Dekkers, 2013 & Mitrella sp. \\
\hline
\end{tabular}

cusp with three secondary cusps along the posterior edge: a narrow, pointed distal cusp, a flat central cusp slightly enlarged at the base, and a quadrangular and apically curved basal cusp.

\section{REMARKS}

Dunker (1853: 24) used Columbella striata Duclos for his specimens from Luanda and Annobon, quite certainly referring to this species. However, Columbella striata Duclos (described from Senegal and here provisionally included in the synonymy of C. rustica) is preoccupied by Columbella striata Menke 1829, a nomen dubium without type(s) availables. The 10 syntypes of Columbella nucleus Kiener at MHNG are to be considered as syntypes as they originate from the Delessert collection, as reported for this species in the original description.
C. xiphitella differs from Columbella rustica by its multispiral protoconch (v. paucispiral in C. rustica). Morphological (including colour pattern) variation in the teleoconch of the three eastern Atlantic species (C. rustica, C. adansoni and C. xiphitella) largely overlaps with no evident diagnostic characters. All shells of $C$. xiphitella examined (including the type series) have strong dentition on columellar and outer lips, and very dark marks between the denticles, features only occasionally present in the other two species. However, the three species are unequivocally separated by molecular data from COI and 16S. Eighteen autapomorphic positions were scored in the COI sequences: 34 [T], 55 [T], 78 [G], $100[\mathrm{~T}], 115[\mathrm{~T}], 117[\mathrm{~A}], 130[\mathrm{~A}], 133$ [C/G], 178 [C], $309[\mathrm{C}], 346[\mathrm{C}], 385[\mathrm{~T}], 430[\mathrm{C}], 463[\mathrm{~T}], 472[\mathrm{G}], 565$ [T], $598[\mathrm{~T}], 619[\mathrm{~T}]$. 


\section{DISCUSSION}

The combined use of molecular data with morphological, geographical and ecological attributes is revealing a growing number of cases of hidden biodiversity in gastropods, often with virtually no morphological distinction in shell characters, among genetically well-separated species (e.g., Modica et al. 2013). In the present case, the three species of Columbella detected in the eastern Atlantic and the Mediterranean are virtually indistinguishable by their teleoconch features, whereas they are neatly separated by genetic data.

Two species were previously accepted after Moolenbeek \& Hoenselaar (1991), Oliverio (1995) and Rolán \& Ryall (1999): Columbella rustica Linnaeus, 1758, ranging through the entire Mediterranean Sea, and extending into the neighbouring Atlantic South to Senegal and Mauritania, and North to Portugal (it is absent in Galicia); and Columbella adansoni Menke, 1853, described from Cape Verde islands, and assumed to occur across Macaronesia, from the Azores to the Canary Islands, and along the West African coast from Mauritania to Angola (Oliverio 1995).

Based on the present data, Columbella adansoni is restricted with certainty only to populations from Macaronesia. West African populations from Mauritania and Senegal North to Morocco (with paucispiral protoconch) are conservatively included in Columbella rustica pending genetic analysis; those from Ghana South to Angola belong to Columbella xiphitella (type locality corrected herein), while those from Mauritania to Ghana should also be assayed genetically, since $C$. adansoni and C. xiphitella (albeit clearly defined genetically) are indistinguishable morphologically.

As already highlighted by Moolenbeek \& Hoenselaar (1991) and Oliverio (1995), Columbella adansoni has a multispiral protoconch indicating planktotrophic larval development, whereas Columbella rustica has a paucispiral protoconch, indicating non-planktotrophic development. Columbella xiphitella, which is phylogenetically the sister to the other two species, has a multispiral protoconch (similar to Columbella adansoni), thus suggesting that the plesiomorphic state in this group was a planktotrophic larva, as is typical of most (if not all) caenogastropod lineages. This is also paralleled by Columbella moinensis deMaintenon, 2000, from the Pliocene to Pleistocene(?) of Costa Rica and Colombia, with planktotrophic development (and multispiral protoconch); this is a clear sibling of Columbella mercatoria (Pliocene to Recent, Caribbean) with lecithotrophic development (and a paucispiral protoconch) (deMaintenon 2000). Within columbellids, sibling species differing mainly or only in their larval development (and thus in their protoconch morphology) are known also in the genera Zafrona Iredale, 1916, Mitrella and Euplica.

The study of large geographic samples in the species involved herein may yield crucial data to analyse the genetic structure and dynamics of populations from closely related species with contrasting larval ecology. These may in turn prove important to define larval ecology drivers in speciation events related to the loss of planktotrophy (Oliverio 1996b), which has produced pairs of sibling species in many lineages of caenogastropods (e.g., Oliverio 1996a, 1997; Duda \& Palumbi 1999).

\section{Acknowledgements}

Emilio Rolán (Vigo) provided samples from West Africa. Laurent Charles (Muséum Sciences et Nature, Bordeaux), Andrea Deneau (The Linnean Society, London), Virginie Héros (MNHN, Paris), Alan J. Kohn (University of Washington, Seattle), Gary Rosenberg (ANSP, Philadelphia), Emmanuel Tardy (MHNG, Genève), are thanked for bibliographic help and precious information on and pictures of type material. Nicolas Puillandre (MNHN) gave us access to unpublished sequences obtained from MNHN expedition material. Serge Gofas (University of Malaga) and Kevin Monsecour (Aarschot) provided very useful criticisms.

\section{REFERENCES}

AdAms A. 1860. - On some new genera and species of Mollusca from Japan. Annals and Magazine of Natural History (3) 5: 299303 [April 1860], 405-413.

ARnaud P. M. 1978. - Révision des taxa malacologiques méditerrannéens introduits par Antoine Risso. Annales du Muséum d'Histoire naturelle de Nice "1977"5: 101-150.

BANDEL K. 1975. — Das Embryonalgehäuse mariner Prosobranchier der Region von Banyuls-Sur-Mer. 1. Teil. Vie et Milieu 25: 83-118.

BoucheT P. \& Gofas S. 2010. - Columbella, in MolluscaBase (2015). Accessed through: World Register of Marine Species at http://www.marinespecies.org/aphia.php?p=taxdetails\&id=137803 on 2016-12-29

CASTRESANA J. 2000. - Selection of conserved blocks from multiple alignments for their use in phylogenetic analysis. Molecular Biology and Evolution 17: 540-552. https://doi.org/10.1093/ oxfordjournals.molbev.a026334

CHENu J. C. 1846-50. - Illustrations Conchyliologiques ou Description et figures de Toutes les Coquilles Connues Vivantes et Fossiles. Paris, A. Franck. Tome Premier. Genre Colombelle, pls 1-27.

Dautzenberg P. 1900. - Croisière du Yacht Chazalie dans l'Atlantique. Mollusques. Mémoires de la Société zoologique de France 13: 145-265, pls 9-10.

DeMaintenon M. J. 2000. - A new species of Columbella (Neogastropoda: Columbellidae) from the Caribbean Neogene. The Nautilus 114: 14-17. https://doi.org/10.5962/bhl.part.29124

DrouËT H. 1858. - Mollusques marins des Îles Açores. Mémoires de la Société académique de l'Aube 22: 53 p.

Drummond A. J., Ashton B., Cheung M., Helen J., Kearse M., Moir R., StOnes-Havas S., Thierer T.\& Wilson A. 2009. Geneious v 4.7. Biomatters, Ltd., Auckland, New Zealand.http:// www.geneious.com/.

DUNKER G. 1853. - Index Molluscorum, quae in itinere ad Guineam Inferiorem collegit Georgius Tams med. dr. / Auctore Guilielmo Dunker ... accedunt novarum specierum diagnosis, Cirripedia nonnulla et $X$ tabulae iconum. T. Fisher, Casselis Cattorum: vi+74, pls 10.

DuClos P. L. 1840. - Histoire naturelle générale et particulière de tous les genres de coquilles univalves marines à l'état vivant et fossiles, publiée par monographie; ou description et classification méthodique de toutes les espèces connues jusqu'à ce jour représentées en couleur avec la figure et l'anatomie d'un assez grand nombre de Mollusques nouvellement découverts, Genre Colombelle. Didot, Paris. 13 pls. https://doi.org/10.5962/bhl.title.84659 
Duda T. F JR. \& Palumbi S. R. 1999. - Developmental shifts and species selection in gastropods. Proceedings of the National Academy of Science of USA 96: 10272-10277.

Folmer O., Black M., Hoeh W., Lutz R. \& Vrijenhoek R. 1994. - DNA primers for amplification of mitochondrial cytochrome c oxidase subunit I from diverse metazoan invertebrates. Molecular Marine Biology and Biotechnology 3: 294-299.

Franc A. 1943. - Études sur le développement de quelques Prosobranches méditerranéens. Thesis, Alger, $159 \mathrm{p}$.

Hasegawa M., Kishino H. \& YanO T. 1985. - Dating of the human-ape splitting by a molecular clock of mitochondrial DNA. Journal of Molecular Evolution 22: 160-174. https://doi. org/10.1007/BF02101694

HAYASHI S. 2003. - The molecular phylogeny of the Buccinidae (Caenogastropoda: Neogastropoda) as inferred from the complete mitochondrial 16S rRNA gene sequences of selected representatives. Molluscan Research 25: 85-98.

HERNÁNDEZ J. M. \& BOYER F. 2005. - Notes on the columbellid fauna from the infralittoral and circalittoral levels of the Canary Islands. Iberus 23 (2): 69-93.

Iredale T. 1916. - On some new and old molluscan names. Proceedings of the Malacological Society of London. 12: 27-37.http:// biodiversitylibrary.org/page/15770460

КАтОн K. \& Tон H. 2008. - Recent developments in the MAFFT multiple sequence alignment program. Briefings in Bioinformatics 9: 286-298. https://doi.org/10.1093/bib/bbn013

KaTOH K., Misawa K., Kuma K. \& Miyata T. 2002. - MAFFT: a novel method for rapid multiple sequence alignment based on fast Fourier transform. Nucleic Acids Research 30: 3059-3066. https://doi.org/10.1093/nar/gkf436

KIENER L. C. 1834-1850. - Spécies général et iconographie des coquilles vivantes comprenant la collection du Muséum d'Histoire naturelle de Paris, la collection Lamarck, celle du prince Masséna (appartenant maintenant à $M$. le $M$. le Baron Delessert) et les découvertes récentes des voyageurs. 138 'livraisons' ['Colombelles': figures in livraisons 59 (1840) and 60-61 (1841), text in livraisons 62-65 (1841)]. Paris, P. Duménil (later Rousseau) and J. B. Ballière, 2132 p., 827 pls.

KNOWLTON N. 2000. - Molecular genetic analyses of species boundaries in the sea. Hydrobiologia 420: 73-90. https://doi. org/10.1023/A:1003933603879

KNUDSEN J. 1950. — Egg capsules and development of some marine prosobranchs from tropical West Africa. Atlantide Report 1: 85-130.

KNUDSEN J. 1995. - Observations on reproductive strategy and zoogeography of some marine prosobranch gastropods (Mollusca) from the Azores. Açoreana, Supplement 1995: 135-158.

LAMARCK J.-B. M. DE 1799. - Prodrome d'une nouvelle classification des coquilles, comprenant une rédaction appropriée des caractères génériques, et l'établissement d'un grand nombre de genres nouveaux. Mémoires de la Société d'Histoire naturelle de Paris 1: 63-91.

LAMARCK J.-B. M. DE. 1822. - Histoire naturelle des animaux sans vertèbres. Tome septième. Paris, published by the Author, $711 \mathrm{p}$.

Leray M., Yang J. Y., Meyer C. P., Mills S. C., Agudelo N., RANWEZ V., BOEHM J. T. \& MACHIDA R. J. 2013. - A new versatile primer set targeting a short fragment of the mitochondrial COI region for metabarcoding metazoan diversity: application for characterizing coral reef fish gut contents. Frontiers in Zoology 10: 34. https://doi.org/10.1186/1742-9994-10-34

LINNAEUS C. 1758. - Caroli Linnaei... systema naturae per regna tria naturae, secundum classes, ordines, genera, species, cum caracteribus, differentiis, synonymis, locis... Editio decima, reformata. Impensis Direct. Laurentii Salvii: Holmiae, Tome 1. Animalia. [Systema Naturae, 10th Edition]. Stockholm, Sweden, v + 823 p. https:// doi.org/10.5962/bhl.title.542

Malaquias M. A. E. \& ReID D. G. 2009. - Tethyan vicariance, relictualism and speciation: evidence from a global molecular phylogeny of the opisthobranch genus Bulla. Journal of Biogeography 36 (9): 1760-1777. https://doi.org/10.1111/j.13652699.2009.02118.x

MENKE K. T. 1829. - Verzeichniss der ansehnlichen ConchylienSammlung des Freiherrn von der Malsburg...: welche hierdurch zum verkaufe dargeboten wird. $\mathrm{H}$. Gelpke, Pyrmont.: vi + 123 p.

MENKE K. T. 1853. - Conchylien von St. Vincent mit kritischen Anmerkungen. Zeitschrift für Malakozoologie 10 (5-6): 67-80.

Modica M. V., Mariottini P., Prkic J. \& Oliverio M. 2013. DNA-barcoding of sympatric species of ectoparasitic gastropods of the genus Cerithiopsis (Mollusca: Gastropoda: Cerithiopsidae) from Croatia. Journal of the Marine Biological Association of the United Kingdom 93 (4): 1059-1065. https://doi.org/10.1017/ S0025315412000926

Modica M. V., Russini V., Fassio G. \& Oliverio M. 2017. — Do larval types affect genetic connectivity at sea? Testing hypothesis in two sibling marine gastropods with contrasting larval development. Marine Environmental Research 127: 92-101. https://doi. org/10.1016/j.marenvres.2017.04.001

Monsecour K. \& Gofas S. 2010a. - Columbella adansoni, in MolluscaBase (2016). Accessed through: World Register of Marine Species at http://www.marinespecies.org/aphia. php?p=taxdetails\&id=139195 on 2016-12-29

Monsecour K. \& Gofas S. 2010b. - Columbella rustica (Linnaeus, 1758), in MolluscaBase (2016). Accessed through: World Register of Marine Species at http://www.marinespecies.org/ aphia.php? $\mathrm{p}=$ taxdetails\&id $=139196$ on 2016-12-29

MoOlenbeek R. G. \& Hoenselaar H. J. 1991. - On the identity of Columbella rustica from West Africa and the Macaronesian Islands. Bulletin of the Zoological Museum, University of Amsterdam 13 (6): 65-70.

Oliverio M. 1995. - Larval development and allozyme variation in the East Atlantic Columbella. Scientia Marina 59 (I): 77-86.

OLIVERIO M. 1996a. — Life-histories, speciation and biodiversity in Mediterranean prosobranchs gastropods. Vie et Mileu 46: 163-169.

Oliverio M. 1996b. - Contrasting developmental strategies and speciation in N. E. Atlantic prosobranchs: a preliminary analysis, in TAYLOR J. D. (ed.), Origin and Evolutionary Radiation of the Mollusca, Vol. 22. Oxford University Press, Oxford: 261-266.

Oliverio M. 1997. — Global biodiversity and life-history evolution in prosobranchs gastropods. Iberus 16: 73-79.

Oliverio M. \& MARIOTTINI P. 2001. — A molecular framework for the phylogeny of Coralliophila and related muricoids. Journal of Molluscan Studies 67: 215-224. https://doi.org/10.1093/mollus/67.2.215

Pallary P. 1900. - Coquilles marines du littoral du Départment d'Oran. Journal de Conchyliologie 48 (3): 211-422, pls 6-8.

Palumbi S., Martin A., Romano S., McMillan W. O., Stice L. \& GrabowsKi G. 2002. - The simple fool's guide to PCR Version 2.0. Honolulu, HI: Department of Zoology and Kewalo Marine Laboratory, University of Hawaii, $45 \mathrm{p}$.

Pelorce J. \& Boyer F. 2005. - La famille Columbellidae (Gastropoda: Muricoidea) dans l'infralittoral de la Péninsule du Cap Vert (Sénégal). Iberus 23 (2): 95-118.

Philippi R. A. 1836. - Enumeratio molluscorum Siciliae cum vivatium tum in tellure tertiaria fossiliumquae in itinere suo observavit. S. Shropp, Berlin, xiv + 267 p., pls 1-12.

Puillandre N., Lambert A., Brouillet S. \& Achaz G. 2012a. ABGD, Automatic Barcode Gap Discovery for primary species delimitation. Molecular Ecology 21: 1864-1877. https://doi. org/10.1111/j.1365-294X.2011.05239.x

Puillandre N., Modica M. V., Zhang Y., Sirovich L., BoisSelier M. C., Cruaud C., Holford M.\& Samadi S. 2012b. Large-scale species delimitation method for hyperdiverse groups. Molecular Ecology 21: 2671-2691. https://doi.org/10.1111/j.1365294X.2012.05559.x

ReID D. G., LAL K., MACKENZIE-DODDS J., KALIGIS F., LiTTLEWOOD D. T. J. \& Williams S. T. 2006. — Comparative phylogeography 
and species boundaries in Echinolittorina snails in the central Indo-West Pacific. Journal of Biogeography 33: 990-1006. https:// doi.org/10.1111/j.1365-2699.2006.01469.x

Risso A. 1826-1827. - Histoire naturelle des principales productions de l'Europe Méridionale et particulièrement de celles des environs de Nice et des Alpes Maritimes. Paris, Levrault: Vol. 4 IV + 439 + 12 pl. (molluscs) [november 1826]. https://doi.org/10.5962/ bhl.title. 58984

RolÁN E. 2005. - Columbellidae (Gastropoda, Neogastropoda) of the gulf of Guinea with the description of eight new species. Iberus 23 (2): 119-156.
Rolán E. \& Ryall P. 1999. - The genus Columbella Swainson, 1840 in the East Atlantic. La Conchiglia 31 (290): 57-58.

Thorsson W. 2003. — Living Columbellidae Part 9. Internet Hawaiian Shell News, November 2003 Feature-3: 1-17, at http:// internethawaiishellnews.org/IHSN/2003/0311fea3.pdf

TrYon G. W. JR. 1883. - Manual of Conchology, Structural and Systematic, with Illustrations of the Species. (1) 5: Marginellidae, Olividae, Columbellidae. Philadelphia, published by the author: 1-276, pls 1-63. http://doi.org/10.5962/bhl.title.6534

Wheeler Q. \& MeIER R. 2000. - Species Concepts and Phylogenetic Theory: A Debate. Columbia University Press, New York, 230 p. 